OPEN ACCESS

Edited by:

Bertrand Kaeffer,

Institut National de recherche pour

l'agriculture, l'alimentation et

l'environnement (INRAE), France

Reviewed by:

Rezvan Noroozi,

Jagiellonian University, Poland

Ondrej Slaby,

Masaryk University, Czechia

${ }^{*}$ Correspondence:

Soudeh Ghafouri-Fard

s.ghafourifard@sbmu.ac.ir

Martin Pichler

martin.pichler@medunigraz.at

Specialty section:

This article was submitted to

Cytokines and Soluble

Mediators in Immunity,

a section of the journal

Frontiers in Immunology

Received: 09 August 2021

Accepted: 20 October 2021

Published: 04 November 2021

Citation:

Taheri M, Barth DA, Kargl J, Rezaei O, Ghafouri-Fard S and Pichler M (2021) Emerging Role of Non-Coding RNAs in Regulation of T-Lymphocyte Function.

Front. Immunol. 12:756042.

doi: 10.3389/fimmu.2021.756042

\section{Emerging Role of Non-Coding RNAs in Regulation of T-Lymphocyte Function}

\author{
Mohammad Taheri ${ }^{1}$, Dominik A. Barth ${ }^{2}$, Julia Kargl ${ }^{3}$, Omidvar Rezaei ${ }^{1}$, \\ Soudeh Ghafouri-Fard ${ }^{4 *}$ and Martin Pichler ${ }^{5,6 *}$
}

1 Skull Base Research Center, Loghman Hakim Hospital, Shahid Beheshti University of Medical Sciences, Tehran, Iran, 2 Division of Oncology, Department of Internal Medicine, Medical University of Graz, Graz, Austria, ${ }^{3}$ Otto Loewi Research Center, Division of Pharmacology, Medical University of Graz, Graz, Austria, ${ }^{4}$ Department of Medical Genetics, School of Medicine, Shahid Beheshti University of Medical Sciences, Tehran, Iran, ${ }^{5}$ Research Unit of Non-Coding RNAs and Genome Editing in Cancer, Division of Clinical Oncology, Department of Internal Medicine, Comprehensive Cancer Center Graz, Medical University of Graz, Graz, Austria, ${ }^{6}$ Department of Experimental Therapeutics, The University of Texas MD Anderson Cancer Center, Houston, TX, United States

T-lymphocytes ( $T$ cells) play a major role in adaptive immunity and current immune checkpoint inhibitor-based cancer treatments. The regulation of their function is complex, and in addition to cytokines, receptors and transcription factors, several non-coding RNAs (ncRNAs) have been shown to affect differentiation and function of T cells. Among these non-coding RNAs, certain small microRNAs (miRNAs) including miR-15a/16-1, miR-125b5p, miR-99a-5p, miR-128-3p, let-7 family, miR-210, miR-182-5p, miR-181, miR-155 and miR-10a have been well recognized. Meanwhile, IFNG-AS1, Inc-ITSN1-2, IncRNA-CD160, NEAT1, MEG3, GAS5, NKILA, Inc-EGFR and PVT1 are among long non-coding RNAs (IncRNAs) that efficiently influence the function of T cells. Recent studies have underscored the effects of a number of circular RNAs, namely circ_0001806, hsa_circ_0045272, hsa_circ_0012919, hsa_circ_0005519 and circHIPK3 in the modulation of T-cell apoptosis, differentiation and secretion of cytokines. This review summarizes the latest news and regulatory roles of these ncRNAs on the function of $T$ cells, with widespread implications on the pathophysiology of autoimmune disorders and cancer.

Keywords: miRNA, IncRNA, circRNA, T cell, cancer, autoimmune

\section{INTRODUCTION}

T-lymphocytes (T-cells) play a central role in adaptive immunity and are involved in the pathogenesis of immune-related disorders and cancer, thus several therapeutic strategies have been developed to stimulate their effector functions (1). During the process of maturation in the thymus, $\mathrm{T}$ cells express $\mathrm{T}$ cell receptors (TCR) on their surface. Moreover, they can express either CD8 or CD4 glycoproteins, thus being categorized as glycoprotein on their surface and are called CD8+ (cytotoxic) or CD4+ cells (helper) T cells (2). Based on the distinctive cytokine profiles, T helper (Th) cells can be categorized to Th1, Th2, Th9, Th17, Th22, regulatory T cells (Tregs), and follicular helper T cells (Tfhs) subtypes (3). Each cell type can be recognized by epigenetic and genetic signatures. For instance, Treg cells are described by over-expression of the FOXP3 
transcription factor (4) Demethylation of the intronic conserved non-coding sequence 2 is required for maintenance of FOXP3 expression and regulation of stability of Tregs upon re-exposure to cytokines (5). In Tregs, this intronic sequence acts a sensor for IL-2 and STAT5 (5). The expression of a number of transcription factors has been shown to be altered in CD8 $+\mathrm{T}$ cells during clearing an Bacterial or Viral infection (6). Notably, it is possible to predict the potential of these cells to make memory cells based on gene signatures (6). For instance, expressions of Bcl-2 and Cdh-1 have been shown to be surged in the memory subset of CD8+ $\mathrm{T}$ cells (6). In addition, chromatin configurations have been found to influence the function of T cells (6). Non-coding RNAs (ncRNAs) carry a regulatory function in several biological processes including implications in immune checkpoint inhibitor treatment (7). Recent studies have highlighted the impact of different classes of non-coding RNAs in $\mathrm{T}$ cell functions. In this review, we highlight the function of microRNAs (miRNAs), long non-coding RNAs (lncRNAs) and circular RNAs (circRNAs) in regulation of T cells. These three classes of ncRNAs have regulatory effects on expression of mRNA coding genes. In fact, lncRNAs and circRNAs can sequester miRNAs and decrease availability of miRNAs. Since miRNAs can inhibit expression of target mRNAs, the sequestering effects of circRNAs and lncRNAs on miRNAs release miRNA targets from inhibitory effects of miRNAs (8).

\section{miRNAs AND T CELL REGULATION}

miRNAs are about 22 nucleotides in length and regulate expression of their target transcripts mostly through binding to their 3' UTR $(9,10)$. These small molecules are generated in the forms of precursors by RNA polymerases II and III. The mature miRNA is generated through a series of cleavage events in the nucleus and cytoplasm (9). Given their various regulatory functions, miRNAs are important players in the regulation of several physiologic and pathophysiologic processes (11). As for the regulation of $\mathrm{T}$-cell differentiation, several examples of important miRNAs have been reported. For instance, miR-15/ 16 hampers $\mathrm{T}$ cell cycle, their survival and differentiation to memory T cells. Experiments in miR-15/16 deficient T cells have shown that these miRNAs directly inhibit the expression of a broad network of genes contributing in the regulation of cell cycle progression, survival, and development of memory cells (12). Another study has shown miR-15a/16-1 silencing in CD4+ T cells leads to the production of higher levels of IL-22, while upregulation of $\mathrm{miR}-15 \mathrm{a} / 16-1$ results in down-regulation of the IL22 expression through suppression of the aryl hydrocarbon receptor. miR-15a/16-1 silenced CD4+ $\mathrm{T}$ cells were superior to wild-type CD4+ T cells in terms of tissue repair capacity because of their higher capability in production of IL-22. Furthermore, IL-22 has been shown to decrease miR-15a/16-1 levels through activation of phosphorylated STAT3-c-myc signaling (13).

A high throughput miRNA profiling in human peripheral $\gamma \delta$ $\mathrm{T}$ cells of healthy subjects has led to identification of 14 differentially expressed miRNAs between $\alpha \beta$ and $\gamma \delta \mathrm{T}$ cells.
While miR-150-5p, miR-450a-5p, miR-193b-3p, miR-365a-3p, miR-31-5p, miR-125b-5p and miR-99a-5p have been upregulated in $\gamma \delta \mathrm{T}$ cells, miR-34a-5p, miR-16-5p, miR-15b-5p, miR-24-3p, miR-22-3p, miR-22-5p and miR-9-5p have had the opposite trend (14). Notably, miR-125b-5p and miR-99a-5p have been found to attenuate the activity of $\gamma \delta \mathrm{T}$ cells and decrease their cytotoxic effects against tumor cells. Up-regulation of miR-125b-5p or miR-99a-5p in $\gamma \delta \mathrm{T}$ cells was shown to suppress the activity of $\gamma \delta \mathrm{T}$ cells and induced their apoptosis. Moreover, miR-125b-5p silencing has increased cytotoxic effects of $\gamma \delta \mathrm{T}$ cells against tumor cells through enhancing the production of IFN- $\gamma$ and TNF- $\alpha$ (14). Overexpression of miR$125 \mathrm{~b}$ has also promoted Treg cells differentiation and suppressed Th17 cell differentiation (15). In addition, miR-125a, a miRNA which has only recently been reported to be involved in myelogenous leukemogenesis (16), could inhibit production of proinflammatory cytokines in CD4+ T cells and Th1/Th17 cell differentiation by targeting ETS-1 (17).

Let-7 family miRNAs are also involved in the regulation of T cells functions. In vivo experiments demonstrated that, let-7g-5p may attenuate the frequency of Th17 cells of rheumatoid arthritis (RA) and block Th17 differentiation (18). Let-7f-5p inhibits Th17 differentiation through targeting STAT3. This miRNA has been found to be downregulated in CD4+ T cells of patients with multiple sclerosis (MS) (19). Finally, let-7d-3p regulates the expression of IL-17 in CD $4+\mathrm{T}$ cells by targeting AKT1 and modulation of AKT1/mTOR signaling pathway (20). miR-210 is another miRNA whose deletion enhances $\mathrm{T}$ cell differentiation and Th17 polarization under hypoxic situation through modulation of HIF-1 $\alpha$ expression (21). Expression of this miRNA has also been found to be over-expressed in both psoriasis patients and psoriasis animal models where it stimulates Th17 and Th1 cell differentiation but suppresses Th2 differentiation via inhibiting expressions of STAT6 and LYN. Ablation of miR-210 in animals and intradermal injection of miR-210 antagonist has reversed the immune imbalance and blocked the development of psoriasis-like inflammatory response in an animal model of psoriasis. TGF- $\beta$ and IL-23 have been shown to increase the expression of miR210 through the induction of HIF-1 $\alpha$, and subsequent recruitment of $\mathrm{P} 300$ and enhancement of histone $\mathrm{H} 3$ acetylation in miR-210 promoter (22).

miR-181c has been shown to enhance Th17 differentiation and promote autoimmunity through targeting Smad7 and modulating TGF- $\beta$ pathway and IL-2 expression (13). Overexpression of miR-181c has suppressed activation of $\mathrm{T}$ cell, impaired cytoskeleton arrangement in $\mathrm{T}$ cells by targeting BRK1 (23). Meanwhile, miR-181a has been reported to restrict IFN $-\gamma$ production by targeting Id 2 so regulating IFN- $\gamma$-mediated CD8+ T cell responses mediated by (24). This miRNA also promotes expression of TGF- $\beta$ and IL-10 and inhibits function of Tregs through modulating the PI3K/Akt pathway (25). Figure 1 illustrates the role of various ncRNAs in regulating the differentiation of $\mathrm{T}$ cells via the PI3K/Akt/mTOR and MAPK/ERK signaling pathways. Table 1 summarizes the impact of miRNAs on regulation of function of $\mathrm{T}$ cells. 


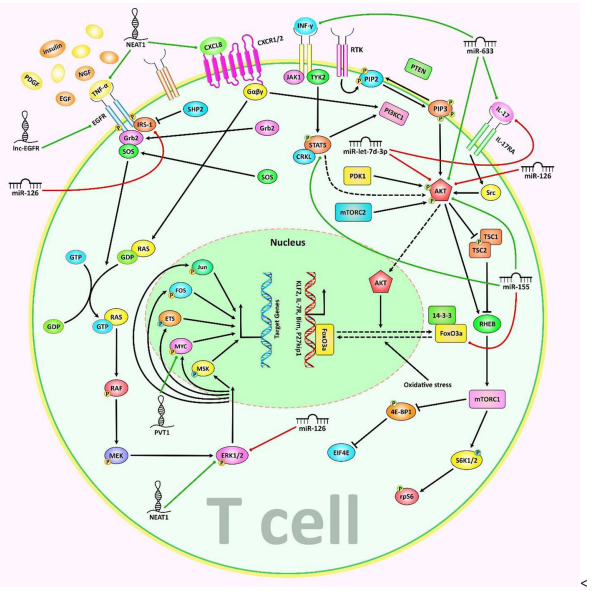

FIGURE 1 | A schematic representation of the role of various non-coding RNAs in modulating the differentiation of T cells via the PI3K/Akt/mTOR and MAPK/ERK signaling cascades. a) The MAPK/ERK pathway can be triggered via several growth factors including PDGF, EGF, NGF, and insulin. Upon receptor dimerization, activation of its tyrosine kinase module could be triggered, subsequently recruiting Grb2 and SOSto the phosphorylated domain, thus creating the Grb2-SOS complex. Furthermore, the GTP binding protein RAS interacts with the Grb-2-SOS complex that in turn leads to the activation of RAS. Activated GTP-bound RAS plays an effective role in upregulating the phosphorylation of MEK1/2 (MAPKK), which then phosphorylates ERK1/2 (MAPK). Eventually, ERK is transferred to the nucleus where it triggers the activation of various target genes involved in a variety of cellular processes (2629). b) The PI3K/Akt/mTOR signaling is activated by a subset of growth factors such as PI3KCl, which phosphorylates PIP2 to PIP3. PIP3 has an important role in recruiting AKT which gets activated through double phosphorylation (via PDK1 and mTORC2). In addition, activated AKT suppresses TSC2 through phosphorylation. Inactive TSC1/2 complex is able to bind RHEB, which eventually triggers the activation of mTORC1. The mTORC1 has a significant impact on many downstream proteins, such as S6K1/2 and 4EBP1 $(30,31)$ Besides, exposure to IL-17 results in receptor-mediated activation of Src, MAPKs, and PI3K/Akt signaling cascades (32). Moreover, subsequent to JAK activation, CRKL is phosphorylated by TYK2 that could result in CRKL complexation with STAT5. STATs in turn interacts with individual mediators of the PI3K/AKT signaling cascade (33). Accumulating finding has demonstrated that miR-let-7d-3p via directly suppressing AKT1 could regulate expression level of $\mathrm{IL}-17$ in CD4+ T cells through the AKT1/mTOR signaling pathway (20). In addition, another research has authenticated that overexpression of IncRNA NEAT1 could promote the expression levels of CXCL8 and TNF- $\alpha$ in Sjögren's syndrome via positively regulating MAPK signaling (34). Green arrows indicate upregulation of target genes modulated via ncRNAs (IncRNAs, and miRNAs), red arrows depict inhibition by these ncRNAs. All the information regarding the role of these ncRNAs in modulating $T$ call differentiation can be seen in and.

\section{LncRNAs AND T CELL REGULATION}

LncRNAs are typically longer than 200 nucleotides and may also be several kilobases long (69). They exert diverse effects on chromatin structure, transcription of genes and posttranscriptional regulation of gene expression (70). These effects are exerted through both chromatin-based mechanisms and the interaction with other types of transcripts. Moreover, by serving as decoy, scaffold, and enhancers, lncRNAs influence genes expressions though various mechanisms (71). Several lncRNAs have been found to influence the function of T cells. For instance, IFNG-AS1 is up-regulated in the intestinal tissue of patients with active inflammatory bowel disease (IBD). Specific overexpression of IFNG-AS1 in T cells has led to significant enhancement of inflammatory cytokines, while attenuation of production of anti-inflammatory cytokines. Media from IFNGAS1-overexpressing $\mathrm{T}$ cells has induced a potent inflammatory response in primary human peripheral blood mononuclear cells (PBMCs) (72). Lnc-ITSN1-2 is another lncRNA that affect T cells differentiation. This lncRNA has been shown to increased proliferation and activation of CD4+ T Cells and promote their differentiation to Th1/Th17 through targeting miR-125a and upregulating IL-23R (73).

The regulatory role of NEAT1 on T cells functions has been validated in different contexts, including sepsis, primary Sjögren's syndrome, RA and hepatocellular carcinoma (HCC) $(74,75)$. Downregulation of NEAT1 has restricted immune response in mouse model of sepsis and induced $\mathrm{T}$ cell apoptosis through modulating miR-125/MCEMP1 axis (76). This lncRNA has been shown to promote expression of CXCL8 and TNF- $\alpha$ and activate MAPK signaling pathway. NEAT1 expression has been up-regulated in CD4+ and CD8+ $\mathrm{T}$ cells of patients with primary Sjögren's syndrome (34). Similarly, this lncRNA has been found to be up-regulated in peripheral blood mononuclear cells of RA patients. Its silencing has led to inhibited differentiation of Th17 cells from CD4+ T cells by downregulating STAT3 through modulating its ubiquitination (77). Finally, NEAT1 has been found to be upregulated in PBMCs of HCC patients parallel with up-regulation of Tim-3. NEAT1 silencing has blocked apoptosis of CD8+T cells and increased their cytolysis function. Further, NEAT1 has been shown to exert such effects through miR-155/Tim-3 pathway. Taken together, NEAT1 has been suggested as an important target for enhancing the efficiency of immunotherapy (78).

MALAT1 is another lncRNA with prominent role in the regulation of $\mathrm{T}$ cell function. This lncRNA regulates Th1/Th2 ratio by sponging miR-155 and modulating expression of CTLA4 (79). On the other hand, MEG3 has been found to enhance proportion of Th17 cells and regulate Treg/Th17 ratio by sponging miR-17 and upregulating ROR $\gamma t$ (80). Moreover, this lncRNA decreases proliferation of CD4+T cell and inhibits Th1 and Th17 differentiation by absorbing miR-23a and modulating expression of TIGIT (81). Figure 2 represents the role of various ncRNAs in regulating the JAK2/STAT3 and NF- $\mathrm{KB}$ signaling pathways in the regulation of function of $\mathrm{T}$ cells. Table 2 summarizes the impact of lncRNAs on $\mathrm{T}$ cell function.

\section{CircRNAs AND T CELL REGULATION}

CircRNAs are another group of ncRNAs that can be occasionally translated into proteins. The enclosed structure of circRNAs has endowed them a certain resistance to RNases and thus increases the stability in different body compartments 
TABLE 1 | miRNAs and T cell regulation.

\begin{tabular}{|c|c|c|c|c|c|c|c|c|}
\hline microRNA & $\begin{array}{l}\text { Expression } \\
\text { pattern }\end{array}$ & Disease & Sample & Cell line & Interaction & $\begin{array}{l}\text { Signaling } \\
\text { pathway }\end{array}$ & Function & Reference \\
\hline $\operatorname{miR}-15 / 16$ & - & - & $\begin{array}{l}\text { miR-15/16 deficient } \\
\text { mouse model }\end{array}$ & $\begin{array}{l}\text { CD4(+) T cells } \\
\text { obtained from mice }\end{array}$ & - & - & $\begin{array}{l}\text { Constrains } \\
\text { formation of } \\
\text { memory } T \text { cells and } \\
\text { confines T cell } \\
\text { survival and cell } \\
\text { cycle through } \\
\text { modulating complex } \\
\text { network of their } \\
\text { target genes } \\
\text { implicated in cell } \\
\text { cycle and survival }\end{array}$ & (12) \\
\hline $\begin{array}{l}\operatorname{miR}-15 a \\
16-1\end{array}$ & - & - & C57BL/6 mice & $\begin{array}{l}\text { Naïve CD4+ } \\
\text { T cells }\end{array}$ & $\mathrm{AHR}$ & - & $\begin{array}{l}\text { Decreasing IL-22 } \\
\text { secretion of CD4+ } \\
\text { T cells through } \\
\text { targeting AHR }\end{array}$ & (13) \\
\hline $\begin{array}{l}\text { miR-125b- } \\
5 p \\
\text { miR-99a- } \\
5 p\end{array}$ & $\begin{array}{l}\text { Downregulated } \\
\text { (in } \gamma \delta \mathrm{T} \text { cells } \\
\text { compared with } \\
\alpha \beta T \text { cells) }\end{array}$ & - & $\begin{array}{l}\text { Peripheral blood obtained } \\
\text { from } 21 \text { healthy donors }\end{array}$ & $\begin{array}{l}\alpha \beta T \text { cells and } \gamma \delta T \\
\text { cells purified from } \\
\text { peripheral blood }\end{array}$ & - & - & $\begin{array}{l}\text { upregulation inhibits } \\
\text { activation of } \gamma \delta T \\
\text { cells and } \\
\text { cytotoxicity to tumor } \\
\text { cells by decreasing } \\
\text { secretion of IFN- } \gamma \\
\text { and TNF- } \alpha \text {. }\end{array}$ & $(14)$ \\
\hline$m i R-125 b$ & $\begin{array}{l}\text { Downregulated (in } \\
\text { in PBMCs and } \\
\text { CD4+ T cells of } \\
\text { patients) }\end{array}$ & $\begin{array}{l}\text { Juvenile idiopathic } \\
\text { arthritis (JIA) }\end{array}$ & $\begin{array}{l}\text { Peripheral blood obtained } \\
\text { from } 16 \text { JIA patients and } \\
22 \text { healthy volunteers, } 24 \\
\text { male DBA } 1 \mathrm{~J} \text { mice }\end{array}$ & CD4+ T cells & - & - & $\begin{array}{l}\text { overexpression } \\
\text { promotes Treg cells } \\
\text { differentiation and } \\
\text { suppresses Th17 } \\
\text { cell differentiation. }\end{array}$ & (15) \\
\hline miR-125a & $\begin{array}{l}\text { Downregulated (in } \\
\text { PBMC of IBD } \\
\text { patients) }\end{array}$ & $\begin{array}{l}\text { Inflammatory } \\
\text { bowel diseases } \\
\text { (IBD) }\end{array}$ & $\begin{array}{l}\text { Blood samples from } 106 \\
\text { IBD patients and } 16 \\
\text { healthy controls, Female } \\
\text { C57BL/ } 6 \text { mice }\end{array}$ & CD4+ T cells & ETS-1 $\uparrow$ & - & $\begin{array}{l}\text { Inhibited production } \\
\text { of proinflammatory } \\
\text { cytokines in CD4+ T } \\
\text { cells and Th1/Th17 } \\
\text { cell differentiation by } \\
\text { targeting ETS-1 }\end{array}$ & $(17)$ \\
\hline $\begin{array}{l}m i R-128- \\
3 p\end{array}$ & $\begin{array}{l}\text { Upregulated (in T } \\
\text { cells RA patients) }\end{array}$ & $\begin{array}{l}\text { Rheumatoid } \\
\text { arthritis (RA) }\end{array}$ & $\begin{array}{l}\text { Blood samples from } 20 \\
\text { patients with RA and } 20 \\
\text { healthy subjects, C57BL/6 } \\
\text { mice }\end{array}$ & Patient derived $T$ cells & TNFAIP3 & $\begin{array}{l}\mathrm{NF}-\kappa \mathrm{B} \\
\text { signaling } \\
\text { pathway }\end{array}$ & $\begin{array}{l}\text { silencing represses } \\
\text { activation of T cells } \\
\text { by upregulating } \\
\text { TNFAIP3 and } \\
\text { inhibiting NF-кB } \\
\text { signaling pathway }\end{array}$ & (35) \\
\hline let $-7 g-5 p$ & $\begin{array}{l}\text { Downregulated (in } \\
\text { plasma of RA } \\
\text { patients) }\end{array}$ & $\begin{array}{l}\text { Rheumatoid } \\
\text { arthritis (RA) }\end{array}$ & $\begin{array}{l}\text { Plasma samples from RA } \\
\text { patients and healthy } \\
\text { controls, C57BL/6 mice, } \\
\text { DBA } 1 / \mathrm{J} \text { mice }\end{array}$ & $\begin{array}{l}\text { CD4+ } \\
\text { T cells }\end{array}$ & - & - & $\begin{array}{l}\text { Upregulation } \\
\text { attenuates Th17 } \\
\text { frequency in RA } \\
\text { mouse model and } \\
\text { blockes Th17 } \\
\text { differentiation. }\end{array}$ & (18) \\
\hline let-7f-5p & $\begin{array}{l}\text { Downregulated (in } \\
\text { CD4+ T cells of } \\
\text { patients with MS) }\end{array}$ & $\begin{array}{l}\text { Multiple sclerosis } \\
\text { (MS) }\end{array}$ & $\begin{array}{l}\text { Blood samples from } 16 \\
\text { RRMS patients and } 16 \\
\text { healthy controls, Female } \\
\text { C57BL/6J mice }\end{array}$ & CD4+ T cell & STAT3 $\uparrow$ & - & $\begin{array}{l}\text { Overexpression } \\
\text { inhibits Th17 } \\
\text { differentiation } \\
\text { through targeting } \\
\text { STAT3. }\end{array}$ & (19) \\
\hline $\begin{array}{l}\text { miR-let-7d- } \\
3 p\end{array}$ & - & $\begin{array}{l}\text { Primary Sjögren's } \\
\text { syndrome (pSS) }\end{array}$ & $\begin{array}{l}\text { Blood samples from pSS } \\
\text { patients and healthy } \\
\text { controls }\end{array}$ & CD4+ T cells & AKT1 & $\begin{array}{l}\text { AKT1/ } \\
\text { mTOR } \\
\text { signaling } \\
\text { pathway }\end{array}$ & $\begin{array}{l}\text { Regulates } \\
\text { expression of IL-17 } \\
\text { in CD } 4+T \text { cells by } \\
\text { targeting AKT1 and } \\
\text { modulation of } \\
\text { AKT1/mTOR } \\
\text { signaling pathway }\end{array}$ & (20) \\
\hline $\begin{array}{l}\operatorname{miR}-183 \\
\operatorname{miR}-96\end{array}$ & $\begin{array}{l}\text { Upregulated } \\
\text { Upregulated } \\
\text { (in patients' T } \\
\text { cells and }\end{array}$ & $\begin{array}{l}\text { Graves' } \\
\text { orbitopathy (GO) }\end{array}$ & $\begin{array}{l}\text { Blood samples from } \\
\text { patients with GO and } \\
\text { normal subjects, TCR-HA } \\
\text { Thy. } 1.1 \text { transgenic mice, } \\
\text { INS-HA/Rag2KO }\end{array}$ & $\begin{array}{l}\text { CD4(+) T cells from } \\
\text { human blood samples } \\
\text { and mice }\end{array}$ & EGR-1 & - & $\begin{array}{l}\text { overexpression was } \\
\text { associated with } \\
\text { lowered EGR-1 } \\
\text { expression and } \\
\text { augmented }\end{array}$ & (36) \\
\hline
\end{tabular}


TABLE 1 | Continued

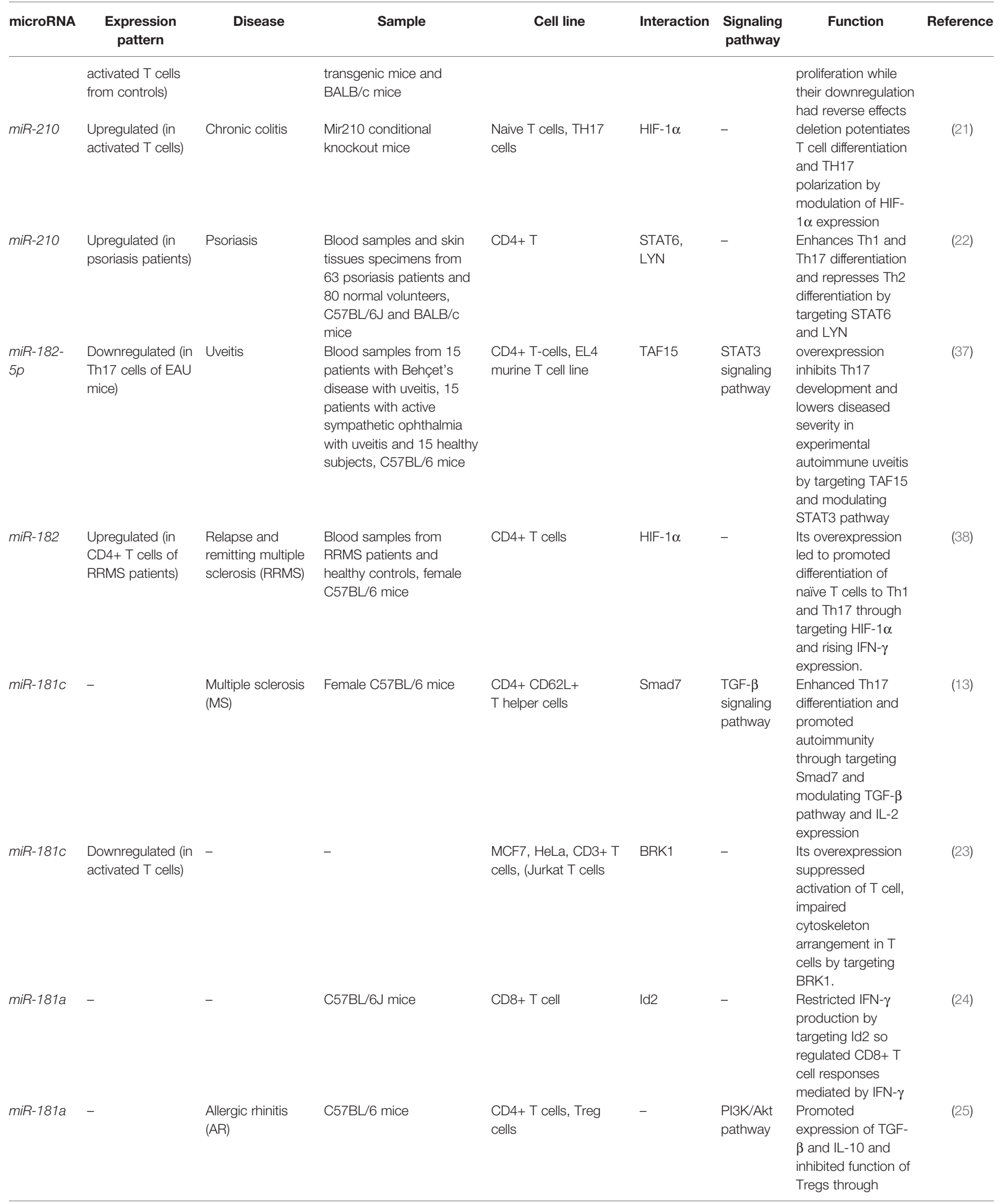


TABLE 1 | Continued

\begin{tabular}{|c|c|c|c|c|c|c|c|c|}
\hline microRNA & $\begin{array}{l}\text { Expression } \\
\text { pattern }\end{array}$ & Disease & Sample & Cell line & Interaction & $\begin{array}{l}\text { Signaling } \\
\text { pathway }\end{array}$ & Function & Reference \\
\hline & & & & & & & $\begin{array}{l}\text { modulating PI3K/ } \\
\text { Akt pathway }\end{array}$ & \\
\hline $\begin{array}{l}\text { miR-202- } \\
5 P\end{array}$ & $\begin{array}{l}\text { Upregulated (in } \\
\text { PBMCs, Tregs, } \\
\text { and CD4+ T cells } \\
\text { of AR patients) }\end{array}$ & $\begin{array}{l}\text { Allergic rhinitis } \\
\text { (AR) }\end{array}$ & $\begin{array}{l}\text { Blood samples from } 30 \\
\text { AR cases and } 10 \text { normal } \\
\text { controls }\end{array}$ & $\begin{array}{l}\text { Tregs cells, CD4+ T } \\
\text { cells }\end{array}$ & MATN2 & - & $\begin{array}{l}\text { Repressed } \\
\text { differentiation of } \\
\text { Tregs by targeting } \\
\text { MATN2 }\end{array}$ & (39) \\
\hline miR-155 & - & Viral infection & $\begin{array}{l}\text { C57BL/6, MiR-155-/-, } \\
\text { wild-type (WT) and } \\
\text { ovalbumin-specific Tcro/ } \\
\text { Tcr } \beta \text { transgenic (OTII) } \\
\text { mice }\end{array}$ & $\mathrm{CD} 4+\mathrm{T}$ & - & - & $\begin{array}{l}\text { Is implicated in } \\
\text { regulation of } \\
\text { proliferation, } \\
\text { activation and } \\
\text { cytokine production } \\
\text { of CD4+ } T\end{array}$ & (41) \\
\hline miR-155 & - & Vitiligo & $\begin{array}{l}\text { Blood samples from one } \\
\text { vitiligo patient and one } \\
\text { healthy donor }\end{array}$ & $\begin{array}{l}\text { naiive } T \text { and } C D 8+T \\
\text { cells }\end{array}$ & - & - & $\begin{array}{l}\text { Its overexpression } \\
\text { decreased } \\
\text { proliferation of CD8 } \\
+ \text { T cells and } \\
\text { enhanced Treg } \\
\text { percentage }\end{array}$ & (42) \\
\hline $\begin{array}{l}\text { miR-149- } \\
3 p\end{array}$ & $\begin{array}{l}\text { Downregulated (in } \\
\text { CD8+ T cells } \\
\text { overexpressing } \\
\text { PD-1) }\end{array}$ & Breast cancer & Female BALB/c mice & $4 \mathrm{~T} 1, \mathrm{CD} 8+\mathrm{T}$ cell & - & - & $\begin{array}{l}\text { Its overexpression } \\
\text { reduced T cell } \\
\text { apoptosis and } \\
\text { expression of T cell } \\
\text { inhibitor receptors, } \\
\text { also promoted } \\
\text { activation of T cells }\end{array}$ & (39) \\
\hline $\operatorname{miR}-143$ & $\begin{array}{l}\text { Upregulated (in } \\
\text { naïve and } \\
\text { memory T cells } \\
\text { compared with } \\
\text { effector T cells) }\end{array}$ & $\begin{array}{l}\text { Esophageal } \\
\text { squamous cell } \\
\text { carcinoma } \\
\text { (ESCC) }\end{array}$ & $\begin{array}{l}13 \text { tumor tissues and } \\
\text { adjacent normal tissues } \\
\text { from } 13 \text { ESCC patients } \\
\text { and blood samples from } \\
10 \text { healthy donors }\end{array}$ & $\begin{array}{l}\text { CD8+ T cell, HER2- } \\
\text { CAR T cells }\end{array}$ & Glut-1 & - & $\begin{array}{l}\text { Its upregulation } \\
\text { promoted } \\
\text { differentiation of } \\
\text { CD8+ T cell to } \\
\text { memory T cells, } \\
\text { raised T cell } \\
\text { cytotoxicity and } \\
\text { decreased } \\
\text { apoptosis by }\end{array}$ & (44) \\
\hline
\end{tabular}


TABLE 1 | Continued

\begin{tabular}{|c|c|c|c|c|c|c|c|c|}
\hline microRNA & $\begin{array}{l}\text { Expression } \\
\text { pattern }\end{array}$ & Disease & Sample & Cell line & Interaction & $\begin{array}{l}\text { Signaling } \\
\text { pathway }\end{array}$ & Function & Reference \\
\hline & & & & & & & $\begin{array}{l}\text { targeting Glut-1 and } \\
\text { regulation of } \\
\text { metabolism }\end{array}$ & \\
\hline miR-17-92 & - & $\begin{array}{l}\text { Chronic graft- } \\
\text { versus-host } \\
\text { disease (cGVHD) }\end{array}$ & $\begin{array}{l}\text { miR-17-92 conditional } \\
\text { knockout }(K O) \text { mice }\end{array}$ & $\mathrm{CD} 4+\mathrm{T}$ & - & - & $\begin{array}{l}\text { Increased } \\
\text { differentiation of Th1 } \\
\text { and Th17 cells, } \\
\text { elevated production } \\
\text { of follicular Th cells } \\
\text { and associated with } \\
\text { scleroderma and } \\
\text { bronchiolitis }\end{array}$ & (45) \\
\hline miR-10a & - & - & $\begin{array}{l}3 \text { Adipose } \\
\text { Tissue healthy subjects, } \\
\text { female C57BL/6 mice }\end{array}$ & $\begin{array}{l}\text { Naiive CD4+ } \\
\text { T cell, adipose tissue } \\
\text { derived mesenchymal } \\
\text { stem cells (AD-MSCs) }\end{array}$ & - & - & $\begin{array}{l}\text { Transfection with } \\
\text { miR-10a-loaded } \\
\text { exosomes derived } \\
\text { from AD-MSCs } \\
\text { elevated expression } \\
\text { of RORYt and } \\
\text { Foxp3 and reduced } \\
\text { expression of T-bet } \\
\text { and led to } \\
\text { differentiation of } \\
\text { naive T cells to } \\
\text { Th17 and Treg }\end{array}$ & (46) \\
\hline $\begin{array}{l}\text { miR-10a- } \\
3 p\end{array}$ & $\begin{array}{l}\text { Downregulated (in } \\
\text { PBMC of LN } \\
\text { patients) }\end{array}$ & $\begin{array}{l}\text { Lupus nephritis } \\
\text { (LN) }\end{array}$ & $\begin{array}{l}\text { Blood samples from } 94 \\
\text { LN patients and } 38 \\
\text { healthy subjects }\end{array}$ & - & REG3A $\uparrow$ & $\begin{array}{l}\text { JAK2/ } \\
\text { STAT3 } \\
\text { pathway }\end{array}$ & $\begin{array}{l}\text { Its upregulation } \\
\text { enhanced Treg cells } \\
\text { and lessened Th17/ } \\
\text { Treg ratio and } \\
\text { alleviated renal } \\
\text { function by } \\
\text { targeting REG3A }\end{array}$ & $(47)$ \\
\hline miR-633 & $\begin{array}{l}\text { Downregulated (in } \\
\text { CD4+T cells of } \\
\text { SLE patients) }\end{array}$ & $\begin{array}{l}\text { Systemic lupus } \\
\text { erythematosus } \\
\text { (SLE) }\end{array}$ & $\begin{array}{l}\text { Blood samples from } 20 \\
\text { SLE patients and } 19 \\
\text { healthy controls }\end{array}$ & $\begin{array}{l}\text { CD4+T cells, Jurkat } \\
\text { cells }\end{array}$ & $\mathrm{AKT} 1 \uparrow$ & $\begin{array}{l}\text { AKT/ } \\
\text { mTOR } \\
\text { pathway }\end{array}$ & $\begin{array}{l}\text { Its downregulation } \\
\text { increased IL-17, } \\
\text { and IFN- } \gamma \\
\text { production and } \\
\text { activated AKT/ } \\
\text { mTOR pathway in } \\
\text { CD4+T cells } \\
\text { through modulating } \\
\text { AKT1 }\end{array}$ & (48) \\
\hline $\begin{array}{l}\text { miR-142- } \\
3 p\end{array}$ & - & $\begin{array}{l}\text { Acute graft versus } \\
\text { host disease } \\
\text { (GVHD) }\end{array}$ & $\begin{array}{l}\text { Blood samples form } \\
\text { volunteer donors, NOD/ } \\
\text { SCID/mice }\end{array}$ & $\begin{array}{l}\text { Thymic-derived } \\
\text { regulatory T cell (tTreg) } \\
\text { (CD4 + CD25 + CD127- } \\
\text { tTreg) }\end{array}$ & ATG16L1 & - & $\begin{array}{l}\text { Its knockdown } \\
\text { enhances survival } \\
\text { and proliferation of } \\
\text { tTregs by } \\
\text { upregulating } \\
\text { expression of } \\
\text { ATG16L1 and } \\
\text { modulating } \\
\text { autophagy }\end{array}$ & (50) \\
\hline $\begin{array}{l}\text { miR-142- } \\
3 p\end{array}$ & - & - & $\begin{array}{l}\text { Blood samples from } \\
\text { healthy volunteers, NOD }\end{array}$ & $\begin{array}{l}\text { Naiive CD4+CD45RA+ } \\
T \text { cells }\end{array}$ & KDM6A & - & $\begin{array}{l}\text { Its knockdown } \\
\text { improved regulatory }\end{array}$ & (51) \\
\hline
\end{tabular}


TABLE 1 | Continued

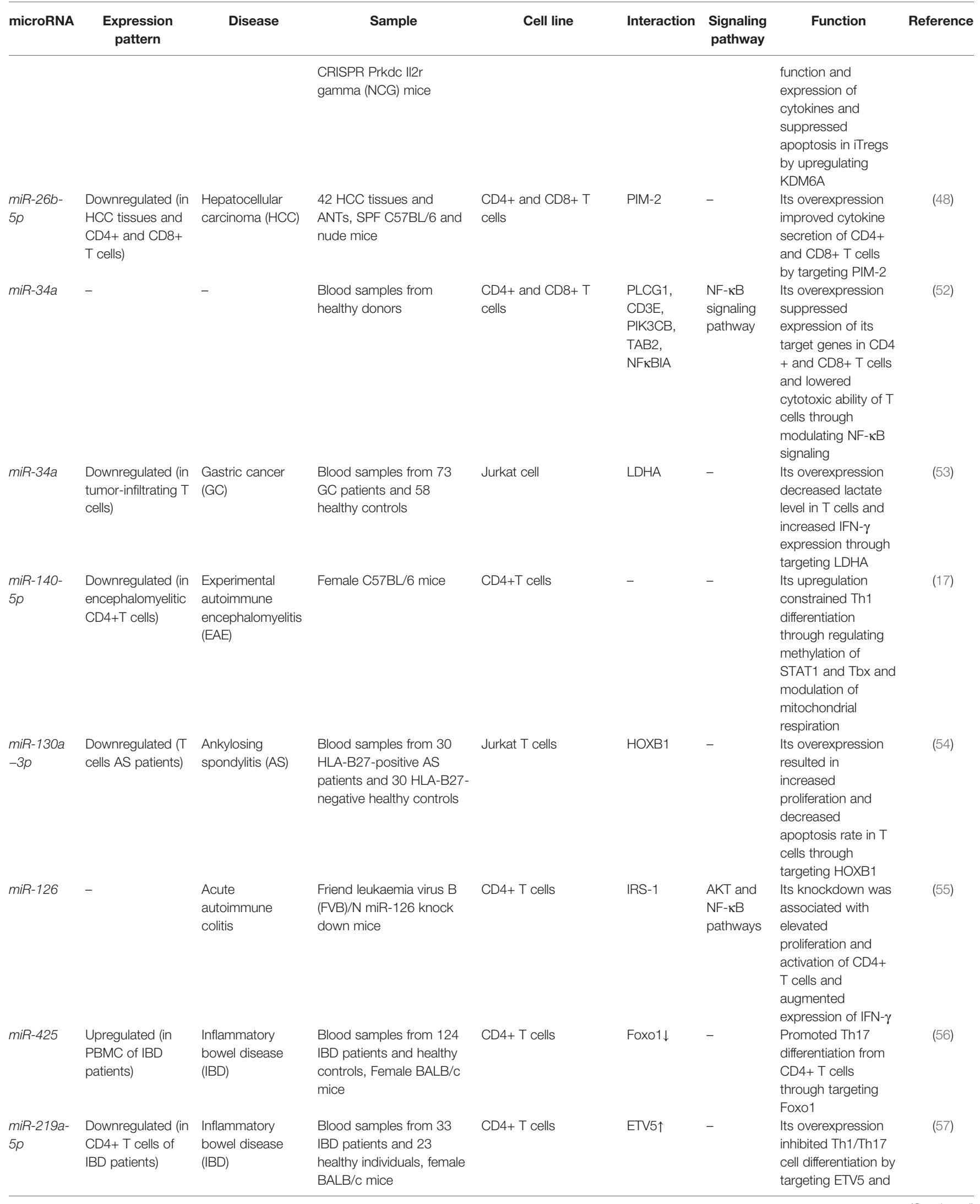


TABLE 1 | Continued

\begin{tabular}{|c|c|c|c|c|c|c|c|c|}
\hline microRNA & $\begin{array}{l}\text { Expression } \\
\text { pattern }\end{array}$ & Disease & Sample & Cell line & Interaction & $\begin{array}{l}\text { Signaling } \\
\text { pathway }\end{array}$ & Function & Reference \\
\hline & & & & & & & $\begin{array}{l}\text { regulating } \\
\text { phosphorylation of } \\
\text { STAT3 and STAT4 }\end{array}$ & \\
\hline miR-22 & $\begin{array}{l}\text { Upregulated (in } \\
\text { intestinal tissues } \\
\text { and CD4+ T cells } \\
\text { of IBD patients) }\end{array}$ & $\begin{array}{l}\text { Inflammatory } \\
\text { bowel disease } \\
\text { (IBD) }\end{array}$ & $\begin{array}{l}\text { Intestinal tissues and } \\
\text { blood samples from } 99 \\
\text { IBD patients, } 15 \text { intestinal } \\
\text { tissues from patients with } \\
\text { colonic polyps and } 20 \\
\text { blood samples from } \\
\text { healthy controls }\end{array}$ & CD4+ T cells & HDAC4 & - & $\begin{array}{l}\text { Elevated Th17 } \\
\text { differentiation and } \\
\text { inflammatory } \\
\text { cytokines } \\
\text { production by } \\
\text { targeting HDAC4 }\end{array}$ & (58) \\
\hline$m i R-21-5 p$ & $\begin{array}{l}\text { Downregulated (in } \\
\text { PBMC of vitiligo } \\
\text { patients) }\end{array}$ & Vitiligo & $\begin{array}{l}\text { Blood samples from } 15 \\
\text { vitiligo patients and } 15 \\
\text { healthy controls }\end{array}$ & CD4+ T cells & STAT3 $\downarrow$ & - & $\begin{array}{l}\text { Its overexpression } \\
\text { increased Treg cells } \\
\text { proportion and } \\
\text { decreased effector } \\
\text { T cells (Teff), so } \\
\text { balanced Treg/Teff } \\
\text { ratio by targeting } \\
\text { STAT3 }\end{array}$ & (59) \\
\hline $\begin{array}{l}\text { miR-223- } \\
3 p\end{array}$ & $\begin{array}{l}\text { Upregulated (in } \\
\text { Th17 cells) }\end{array}$ & $\begin{array}{l}\text { Experimental } \\
\text { autoimmune } \\
\text { uveitis }\end{array}$ & Female C57BL/6 & CD4+ T cells & FOXO3 & - & $\begin{array}{l}\text { Induced } \\
\text { autoreactive Th17 } \\
\text { responses by } \\
\text { targeting FOXO3 } \\
\text { and modulation of } \\
\text { IL-23 receptor } \\
\text { expression }\end{array}$ & (60) \\
\hline $\begin{array}{l}\text { miR-669b- } \\
3 p\end{array}$ & - & - & $\begin{array}{l}\text { C57BL/6 }(\mathrm{H}-2 \mathrm{~b}) \text { and } \\
\text { BALB/c }(\mathrm{H}-2 \mathrm{~d}) \text { mice }\end{array}$ & CD4+ T cells & - & - & $\begin{array}{l}\text { Increased } \\
\text { proliferation of CD4 } \\
+T \text { cells and } \\
\text { restrained apoptosis } \\
\text { of these cells by } \\
\text { negative regulation } \\
\text { of IDO }\end{array}$ & (61) \\
\hline miR-146a & $\begin{array}{l}\text { Upregulated (in } \\
\text { CD27- } \gamma \delta \text { T cells) }\end{array}$ & - & $\begin{array}{l}\text { C57BL/6J and CD45.1 } \\
\text { mice, Rag2-/- mice, } \\
\text { II17a-GFP knock-in mice, } \\
\text { miR-146a-/- mice, Nod1 } \\
\text {-/- and Atf2-/- mice }\end{array}$ & $\begin{array}{l}\text { CD27- } \gamma \delta \text { T cells and } \\
\text { CD27+ } \gamma \delta \text { T cells, CD4 } \\
+T \text { cells }\end{array}$ & NOD1 & & $\begin{array}{l}\text { Decreased IFN- } \gamma \\
\text { production and } \\
\text { restricted functional } \\
\text { plasticity of } \gamma \delta \top \\
\text { cells through } \\
\text { targeting NOD1 }\end{array}$ & (62) \\
\hline miR-29b & $\begin{array}{l}\text { Upregulated (in } \\
\text { CD4+ T cells of } \\
\text { OLP patients) }\end{array}$ & $\begin{array}{l}\text { Oral lichen planus } \\
(\mathrm{OLP})\end{array}$ & $\begin{array}{l}\text { Blood samples form } 18 \\
\text { OLP patients and } 18 \text { age- } \\
\text { and gender-matched } \\
\text { controls }\end{array}$ & $\begin{array}{l}\text { CD4+ } \\
\text { T cells }\end{array}$ & - & - & $\begin{array}{l}\text { Inhibited IFN- } \gamma \\
\text { expression and } \\
\text { secretion in CD4+ T } \\
\text { cells, also } \\
\text { suppressed } \\
\text { expression of } \\
\text { DNMT1 induced } \\
\text { global DNA } \\
\text { hypomethylation in } \\
\text { CD4+ T cells to Th1 } \\
\text { responses }\end{array}$ & (63) \\
\hline miR-31 & $\begin{array}{l}\text { Upregulated (in } \\
\text { peripheral blood } \\
\text { of CHD patients) }\end{array}$ & $\begin{array}{l}\text { Coronary heart } \\
\text { disease }(\mathrm{CHD})\end{array}$ & $\begin{array}{l}\text { Blood samples from } 56 \\
\text { CHD patients and } 47 \text { non- } \\
\text { CHD individuals }\end{array}$ & CD4+ T cells & Bach2 & - & $\begin{array}{l}\text { Increased Th22 } \\
\text { differentiation by } \\
\text { targeting Bach2 }\end{array}$ & (64) \\
\hline $\operatorname{miR}-653$ & $\begin{array}{l}\text { Downregulated (in } \\
\text { thymic tissues of } \\
\text { MG mice) }\end{array}$ & $\begin{array}{l}\text { Myasthenia gravis } \\
\text { (MG) }\end{array}$ & $\begin{array}{l}\text { Thymic tissues from } 42 \\
\text { MG patients, BALB/c } \\
\text { male nude mice }\end{array}$ & $\begin{array}{l}\text { Thymocytes obtained } \\
\text { from thymic tissues }\end{array}$ & TRIM9 & - & $\begin{array}{l}\text { Its overexpression } \\
\text { decreased viability } \\
\text { of thymocytes and } \\
\text { induced cell cycle } \\
\text { arrest and } \\
\text { apoptosis in these } \\
\text { cells by targeting } \\
\text { TRIM9 }\end{array}$ & (65) \\
\hline miR-192 & $\begin{array}{l}\text { Downregulated (in } \\
\text { plasma and CD4+ }\end{array}$ & $\begin{array}{l}\text { Childhood } \\
\text { asthma }\end{array}$ & $\begin{array}{l}\text { Blood samples from } 18 \\
\text { children with childhood }\end{array}$ & CD4+ T cells & CXCR5 & - & $\begin{array}{l}\text { Its overexpression } \\
\text { impeded activation }\end{array}$ & (66) \\
\hline
\end{tabular}


TABLE 1 | Continued

\begin{tabular}{|c|c|c|c|c|c|c|c|c|}
\hline microRNA & $\begin{array}{l}\text { Expression } \\
\text { pattern }\end{array}$ & Disease & Sample & Cell line & Interaction & $\begin{array}{l}\text { Signaling } \\
\text { pathway }\end{array}$ & Function & Reference \\
\hline & $\begin{array}{l}\text { T cells of asthma } \\
\text { patients) }\end{array}$ & & $\begin{array}{l}\text { asthma and } 15 \text { healthy } \\
\text { children }\end{array}$ & & & & $\begin{array}{l}\text { of } \mathrm{T} \text { follicular helper } \\
\text { cells by targeting } \\
\text { CXCR5 }\end{array}$ & \\
\hline $\begin{array}{l}\text { miR-23a- } \\
3 p\end{array}$ & $\begin{array}{l}\text { Downregulated (in } \\
\text { CD4+ T cells of } \\
\text { GD patients) }\end{array}$ & $\begin{array}{l}\text { Graves' disease } \\
\text { (GD) }\end{array}$ & $\begin{array}{l}\text { Blood samples from } 32 \\
\text { GD patients and } 20 \\
\text { healthy individuals, female } \\
\text { Balb/c mice }\end{array}$ & CD4+ T cell, 293T & SIRT1 & - & $\begin{array}{l}\text { Its overexpression } \\
\text { enhanced Treg } \\
\text { frequency and } \\
\text { improved function } \\
\text { of Tregs by } \\
\text { targeting SIRT1 and } \\
\text { modulating FOXP3 } \\
\text { expression and } \\
\text { acetylation }\end{array}$ & (67) \\
\hline $\begin{array}{l}m i R-133 a \\
133 b\end{array}$ & $\begin{array}{l}\text { Upregulated (in } \\
\text { PBMC of IgAN } \\
\text { patients) }\end{array}$ & $\begin{array}{l}\text { IgA nephropathy } \\
(\operatorname{IgAN})\end{array}$ & $\begin{array}{l}\text { Blood samples form } 20 \\
\text { lgAN patients and heakthy } \\
\text { controls }\end{array}$ & CD4+ T cells & FOXP3 & - & $\begin{array}{l}\text { Inhibited Treg } \\
\text { differentiation and } \\
\text { decreased Treg } \\
\text { frequency by } \\
\text { downregulating } \\
\text { FOXP3 }\end{array}$ & (68) \\
\hline
\end{tabular}

(108). A genome wide transcriptome profiling of circRNAs has revealed that the median length of circRNAs is about $530 \mathrm{nt}$ (109). Four categories of circRNA shave been identified: exonic circRNAs, circRNAs from introns, exon-intron circRNAs and intergenic circRNAs (110). The impact of this group of transcripts on $\mathrm{T}$ cell functions has been discovered during the recent decade. Several studies have shown that circRNAs can bind with miRNAs, thus decreasing bioavailability of miRNAs and releasing miRNA targets from their inhibitory effects. This kind of interactions between circRNAs and miRNAs has critical biological impacts. A high-throughput microarray study found down-regulation of circ_0001806 in patients with cryptococcal meningitis as compared to healthy controls. Circ_0001806 silencing has increased the intensity of fungal infection in the animal models and decreased their survival. Circ_0001806 has been suggested to regulate molecular cascades associated with the host antimicrobial response in $\mathrm{T}$ cells. Functionally, circ_0001806 has been shown to increase ADM level, decrease cell apoptosis and reverse G1/S arrest in $\mathrm{T}$ cells through sequestering miR-126. Thus, circRNA-1806/miR-126 cascade has an essential role in the regulation of cell cycle and apoptosis in T cells (111).

Another high throughput circRNA profiling in patients with systemic lupus erythematosus (SLE) has led to identification of 127 differentially expressed circRNAs in $\mathrm{T}$ cells of these patients. Among them, circRNA hsa_circ_0045272 has been reported to be the down-regulated. Functional studies have shown that hsa_circ_0045272 silencing increases early apoptosis of Jurkat cells and enhances production of IL-2 by activated Jurkat cells. Binding of this circRNA with hsa-miR6127 has been validated through functional studies (112). Hsa_circ_0012919 has been reported to be up-regulated in CD4+ T cells of SLE patients in two independent studies. In a microarray study of circRNAs signature in these patients, hsa_circ_0012919 has been among differentially expressed circRNAs between SLE patients and healthy subjects.
Expression of this circRNA has been associated with SLE features. Down-regulation of hsa_circ_0012919 has enhanced expression of DNMT1, decreased CD70 and CD11a levels and inverted the DNA hypomethylation of these genes in CD4+ T cells of SLE. Hsa_circ_0012919 has been found to regulate expressions of KLF13 and RANTES through sequestering miR125a (113). This circRNA has also been found to increase the expression of MDA5 in CD4+ T cells through downregulating miR-125a-3p (114). Hsa_circ_0005519 is another circRNA influencing $\mathrm{T}$ cell function. This circRNA has been found to be up-regulated in CD4+ T cells of asthmatic patients. Expression of this circRNA has been inversely correlated with hsa-let-7a-5p levels. Expression of hsa_circ_0005519 in CD4+ $\mathrm{T}$ cells has been correlated with fraction of exhaled nitric oxide and eosinophil ratio in the circulation of these patients. Hsa_circ_0005519 has been predicted to sequester hsa-let-7a$5 p$ and release IL-13/IL-6 from its inhibitory effect (115). Being up-regulated circRNA in nasal mucosa of patients with allergic rhinitis, circHIPK3 has been found to promote differentiation of CD4+ T cells to Th2 by targeting miR-495 and increasing expression of GATA-3 (116). Figure 3 illustrates the role of different ncRNAs in Th2-cell differentiation through modulating the IL-4-STAT6-GATA3 axis. Table 3 shows the impact of circRNAs on $\mathrm{T}$ cell function.

\section{SUMMARY}

Numerous miRNAs, lncRNAs and circRNAs have been found to influence activity, survival or differentiation of $\mathrm{T}$ cells under physiologic or pathologic conditions. These molecules can affect pathophysiology of autoimmune conditions such as MS, SLE, RA, IBD and asthma via this route. Moreover, several of these non-coding RNAs influence immune evasion of cancer cells and their response to immunotherapeutic modalities. 


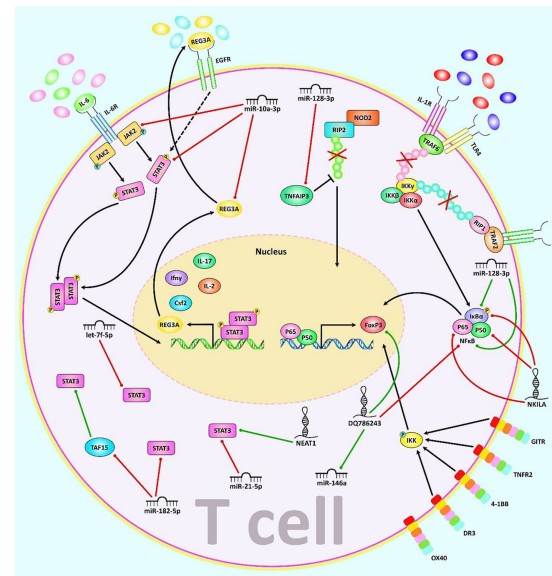

FIGURE 2 | A schematic illustration of the role of various noncoding-RNAs in modulating the JAK2/STAT3 and NF-KB signaling pathway as major regulators of T cell function. a) In JAK/STAT pathway, JAKs bind to the receptor, and upon multimerization, upregulation of JAK proteins is mediated via transphosphorylation. Consequently, JAKs have a significant part in STATs phosphorylation. After dimerization of STATs, they translocate to the nucleus, where they either activate or suppress several target genes. This cascade is remarkably involved in the control of immune responses. Dysregulation of JAKSTAT signaling is associated with different immune disorders $(82,83)$. Besides, REG3A, acts as a key molecule for overexpression of the JAK2/STAT3 pathway which effectively contributes to triggering inflammation (84). b) The NF-kB canonical or classical signaling pathway is initiated from the cell surface receptor of pro-inflammatory cytokines and PAMPs containing TNFR, TLR and $\mathrm{T} / \mathrm{B}$ cell receptor. The activation of IKK complex is triggered via binding of ligand molecules to transfer the signal across the cell surface. This complex generally comprises heterodimer of IKK $\alpha$ and IKK $\beta$ catalytic subunits and an IKK $\gamma$ regulatory subunit. The released NF-kB dimers (most generally the p50P65 dimer) could be translocated to the nucleus, and bind to DNA to trigger activation of the down-stream gene transcription (85-87). In addition, NF- $\mathrm{KB}$ signaling cascade could be regulated via TNFAIP3 through deubiquitinating TNFR1-RIP1, IL-1R/TLR4-TRAF6, and NOD2-RIP2 pathways (88). Moreover, canonical NF-kB cascade could be activated by various members of the TNFRSF including GITR, TNFR2, 4-1BB, and DR3 but not OX40 in Treg cells and modulates induction of Foxp3, markers of Th2/Th17 response (89). Mounting studies have revealed that multiple ncRNAs (IncRNAs and miRNAs) have an effective role in as major regulators of $T$ cell function through regulating the JAK/STAT and NF- $\mathrm{kB}$ cascades. As an illustration, recent research has detected that downregulation of miR-128-3p could notably reduce the inflammation response of rheumatoid arthritis via attenuating the activity of NF$\kappa B$ pathway and promote expression of TNFAIP3 (35). Another study has figured out that reducing the expression of IncRNA NEAT1 could lead to suppression of Th17/CD4+ T cell differentiation via downregulating STAT3 expression in rheumatoid arthritis patients (77). Furthermore, upregulation of DQ786243 could play a remarkable role in elevating the expression level of miR-146a through modulating Foxp3, and thereby suppressing the NF- $\mathrm{KB}$ signaling cascade in oral lichen planus disease (90). Green arrows indicate upregulation of target genes modulated via ncRNAs (IncRNAs, and miRNAs), red arrows depict inhibition by these ncRNAs. All the information regarding the role of these ncRNAs in modulating $T$ call differentiation can be seen in

Tables 1, 2

Notably, both lncRNAs and circRNAs can serve as sponges for miRNAs. Through this molecular mechanism, lncRNAs and circRNAs bind with certain miRNAs to decrease their bioavailability. Thus, circRNAs and $\operatorname{lncRNAs}$ can indirectly affect expression of miRNAs targets. Circ_0001806/miR-126, hsa_circ_0045272/hsa-miR-6127, hsa_circ_0012919/miR-125, hsa_circ_0005519/hsa-let-7a-5p, circHIPK3/miR-495 are examples of circRNA/miRNA axes regulating $\mathrm{T}$ cell functions. In addition, lnc-ITSN1-2/miR-125a, NEAT1/miR-125, NEAT1/ miR-155, MALAT1/miR-155, MEG3/miR-17, MEG3/miR-23a, Gm15575/miR-686 are examples of lncRNA/miRNA pairs in this regard. These examples not only indicate the intricate network between these classes of transcripts, but also provide clues to find the most important modules in the regulation of $\mathrm{T}$ cell functions. Contribution of miR-125, miR-155, MEG3 and NEAT1 in more than one of these molecular axes suggests their significance in the regulation of $\mathrm{T}$ cell function. Most notably, all of these four non-coding RNAs have essential roles in cancer development or suppression (118-120), further highlighting the intercalation of cancer-related and immune-related molecular pathways.

GATA3, ROR $\gamma$ t, NF- $\mathrm{kB}$, SIRT1, STAT3 and FOXO3 as major regulators of $\mathrm{T}$ cell function have been shown to be influenced by non-coding RNAs. For instance, GATA3 is influenced by Dreg1 and GATA3-AS1 lncRNAs; ROR $\gamma$ t is regulated by MEG3; SIRT1 is modulated by miR-155 and miR-23a-3p; STAT3 is regulated by let-7f-5p, miR-182-5p and miR-10a-3p, miR-21-5p and NEAT1; and FOXO3 is controlled by miR-155. Therefore, non-coding RNAs affect $\mathrm{T}$ cells functions through different routes.

Consistent with the important roles of lncRNAs, circRNAs and miRNAs in the regulation of function of $\mathrm{T}$ cells and their impact on differentiation of different classes of $\mathrm{T}$ cells, therapeutic targeting of these ncRNAs represent an efficient tool for management of disorders related with abnormal function of $\mathrm{T}$ cells. Forced up-regulation or silencing of these transcript can affect signaling pathways that modulate $\mathrm{T}$ cell responses, thus alleviating tissue damage caused by abnormal $\mathrm{T}$ cell responses. Moreover, assessment of ncRNAs signature is a probable strategy for prediction of course of T cell-related disorders.

Taken together, the significant impact of non-coding RNAs on differentiation, survival, cytokine production and activity of T cells potentiates these molecules as important targets for treatment of various disorders, particularly cancer. Moreover, non-coding RNAs participate in the pathogenesis of autoimmune disorders via affecting epigenetic regulation of genes with crucial roles in the regulation of effector $\mathrm{T}$ cells as well as Tregs (121). Thus, identification of the role of these transcripts in the regulation of $\mathrm{T}$ cell functions can provide new modalities for treatment of this kind of disorders as well. High throughput sequencing method and assessment of the competing endogenous RNA network through bioinformatics methods is an efficient strategy in identification of appropriate targets for therapeutic interventions.

\section{FUTURE PERSPECTIVES}

High throughput sequencing strategies and identification of differential expressions of lncRNAs, circRNAs, miRNAs 
TABLE 2 | LncRNAs and T cell regulation.

\begin{tabular}{|c|c|c|c|c|c|c|c|c|}
\hline IncRNA & $\begin{array}{l}\text { Expression } \\
\text { pattern }\end{array}$ & Disease & Sample & Cell line & Interaction & $\begin{array}{l}\text { Signaling } \\
\text { pathway }\end{array}$ & Function & Reference \\
\hline IFNG-AS1 & $\begin{array}{l}\text { Upregulation (in } \\
\text { colonic tissues } \\
\text { of IBD patients) }\end{array}$ & $\begin{array}{l}\text { Inflammatory } \\
\text { bowel diseases } \\
\text { (IBD) }\end{array}$ & $\begin{array}{l}\text { Colonic tissues from } 11 \\
\text { IBD patients, }\end{array}$ & $\begin{array}{l}\text { PBMCs from } \\
\text { anonymous } \\
\text { donors, } \\
\text { Jurkat cells }\end{array}$ & - & - & $\begin{array}{l}\text { Its overexpression } \\
\text { augmented inflammatory } \\
\text { cytokines expression and } \\
\text { decrease anti-inflammatory } \\
\text { cytokines expression in T } \\
\text { cells. }\end{array}$ & (72) \\
\hline Inc-ITSN1-2 & $\begin{array}{l}\text { Upregulation (in } \\
\text { intestinal } \\
\text { mucosa and } \\
\text { PBMC of IBD } \\
\text { patients) }\end{array}$ & $\begin{array}{l}\text { Inflammatory } \\
\text { bowel diseases } \\
\text { (IBD) }\end{array}$ & $\begin{array}{l}\text { Blood samples and } \\
\text { intestinal mucosa } \\
\text { specimens from } 120 \\
\text { IBD patients and } 30 \\
\text { healthy controls }\end{array}$ & CD4+ T Cells & $\begin{array}{l}\operatorname{miR}-125 a \\
\text { IL-23R }\end{array}$ & - & $\begin{array}{l}\text { Increased proliferation and } \\
\text { activation of CD4+ T Cells } \\
\text { and promoted their } \\
\text { differentiation to Th1/Th17 } \\
\text { by targeting miR-125a and } \\
\text { upregulation of IL-23R }\end{array}$ & (73) \\
\hline IncRNA-CD160 & $\begin{array}{l}\text { Upregulated (in } \\
\text { CD8+ T cells of } \\
\text { HBV infected } \\
\text { patients) }\end{array}$ & $\begin{array}{l}\text { Chronic } \\
\text { hepatitis B } \\
\text { virus (HBV) } \\
\text { infection }\end{array}$ & $\begin{array}{l}\text { Blood samples from } \\
164 \text { patients with } \\
\text { chronic HBV infection } \\
\text { and } 67 \text { healthy } \\
\text { volunteers, } \mathrm{C} 3 \mathrm{H} / \mathrm{HeN} \\
\text { mice }\end{array}$ & $\begin{array}{l}\text { CD160- CD8 } \\
+\mathrm{T} \text { cells and } \\
\text { CD160+ CD8 } \\
+T \text { cells }\end{array}$ & - & - & $\begin{array}{l}\text { Decreased secretion of } \\
\text { IFN- } \gamma \text { and TNF- } \alpha \text { and } \\
\text { repressed function of CD } 8 \\
+T \text { cells by recruiting } \\
\text { HDAC11 to promoters of } \\
\text { IFN- } \gamma \text { and TNF- } \alpha \text { and } \\
\text { elevating methylation of } \\
\text { H3K9Me1 }\end{array}$ & (91) \\
\hline NEAT1 & - & Sepsis & $\begin{array}{l}130 \text { specific pathogen- } \\
\text { free C57BL/ } 6 \text { male mice }\end{array}$ & $\begin{array}{l}\text { CD4+ } \\
\text { CD25+ T } \\
\text { cells }\end{array}$ & $\begin{array}{l}\text { miR-125, } \\
\text { MCEMP1 }\end{array}$ & - & $\begin{array}{l}\text { Downregulation of NEAT1 } \\
\text { has restricted immune } \\
\text { response in mouse model } \\
\text { of sepsis and induced T } \\
\text { cell apoptosis through } \\
\text { modulating miR-125/ } \\
\text { MCEMP1 axis }\end{array}$ & (76) \\
\hline NEAT1 & $\begin{array}{l}\text { Upregulated (in } \\
\text { CD4+ and CD8 } \\
+T \text { cells of } \\
\text { pSS patients) }\end{array}$ & $\begin{array}{l}\text { Primary } \\
\text { Sjögren's } \\
\text { syndrome } \\
\text { (pSS) }\end{array}$ & $\begin{array}{l}\text { Blood samples from } 20 \\
\text { pSS patients and } 10 \\
\text { healthy subjects }\end{array}$ & $\begin{array}{l}\text { CD4+, CD8+ } \\
\text { and CD19+ T } \\
\text { cells, Jurkat } \\
\text { cells }\end{array}$ & - & $\begin{array}{l}\text { MAPK } \\
\text { signaling } \\
\text { pathway }\end{array}$ & $\begin{array}{l}\text { Promoted expression of } \\
\text { CXCL } 8 \text { and TNF- } \alpha \text { and } \\
\text { activated MAPK signaling } \\
\text { pathway }\end{array}$ & (34) \\
\hline NEAT1 & $\begin{array}{l}\text { Upregulated (in } \\
\text { the PBMCs of } \\
\text { patients with } \\
\text { RA) }\end{array}$ & $\begin{array}{l}\text { Rheumatoid } \\
\text { arthritis (RA) }\end{array}$ & $\begin{array}{l}\text { Blood samples from } 25 \\
\text { RA patients and } 20 \\
\text { healthy controls, Male } \\
\text { DBA } 1 \mathrm{~J} \text { mice }\end{array}$ & CD4+ T cell & STAT3 & - & $\begin{array}{l}\text { Its silencing prevented } \\
\text { differentiation of Th17 cells } \\
\text { from CD4+ T cells by } \\
\text { downregulating STAT3 } \\
\text { through modulating its } \\
\text { ubiquitination. }\end{array}$ & $(77)$ \\
\hline NEAT1 & $\begin{array}{l}\text { Upregulated (in } \\
\text { PBMCs of } \\
\text { HCC patients) }\end{array}$ & $\begin{array}{l}\text { Hepatocellular } \\
\text { carcinoma } \\
\text { (HCC) }\end{array}$ & $\begin{array}{l}\text { Blood samples from } 20 \\
\text { HCC patients and } 20 \\
\text { healthy controls }\end{array}$ & CD8+ T cells & 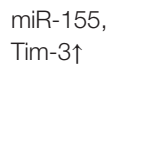 & - & $\begin{array}{l}\text { Its knockdown decreased } \\
\text { apoptosis and raised } \\
\text { cytotoxicity of CD } 8+T \text { cells } \\
\text { by miR-155-mediated } \\
\text { downregulation of Tim-3. }\end{array}$ & (78) \\
\hline Inc-EGFR & $\begin{array}{l}\text { Upregulated (in } \\
\text { Treg cells of } \\
\text { HCC patients) }\end{array}$ & $\begin{array}{l}\text { Hepatocellular } \\
\text { carcinoma } \\
\text { (HCC) }\end{array}$ & $\begin{array}{l}\text { Blood and tissue } \\
\text { samples from } 70 \text { HCC } \\
\text { patients and } 55 \text { healthy } \\
\text { controls }\end{array}$ & $\begin{array}{l}\text { CD4+ T cells, } \\
\text { tumor } \\
\text { infiltrated } \\
\text { lymphocytes } \\
\text { (TIL), } 97 \mathrm{H}, \\
\text { Huh7 }\end{array}$ & EGFR & - & $\begin{array}{l}\text { Induced differentiation of } \\
\text { Treg cells and impeded } \\
\text { CTLs function through } \\
\text { stabilizing EGFR by } \\
\text { interfering with its } \\
\text { ubiquitination }\end{array}$ & (92) \\
\hline PVT1 & $\begin{array}{l}\text { Upregulated (in } \\
\text { the CD } 4+T \\
\text { cells of patients } \\
\text { with SS) }\end{array}$ & $\begin{array}{l}\text { Sjögren's } \\
\text { syndrome (SS) }\end{array}$ & $\begin{array}{l}\text { Blood samples and } \\
\text { labial salivary gland } \\
\text { tissues from SS patients } \\
\text { and healthy controls, } \\
\text { female C57BL/6 mice, } \\
\text { NOD/ShiLtj mice and } \\
\text { wild-type ICR mice }\end{array}$ & CD4+ T cell & Myc & - & $\begin{array}{l}\text { Its downregulation } \\
\text { decreased CD4+ T cells } \\
\text { proliferation and impeded } \\
\text { effector function in these } \\
\text { cells through } \\
\text { downregulation of Myc and } \\
\text { controlling glycolysis }\end{array}$ & (93) \\
\hline IncRNA Morrbid & - & Viral infection & $\begin{array}{l}\text { C57BL/6 (WT), B6.SJL- } \\
\text { Ptprc }^{\text {a Pepc }} \text { /Boy } \\
\text { (B6.SJL), and } \\
\text { B6.129S1- } \\
\text { Bcl2l11 } \\
\text { knock-out) mice, }^{\text {tm } 1 \text { Ast/J }} \text { (Bcl2l11 } \\
\left.\text { Ifnar1 }^{\text {tm1.1Ees }} \text { (Ifnar1 }^{\text {flox }}\right) \text {, }\end{array}$ & CD8+ T cells & - & $\begin{array}{l}\text { PI3K-AKT } \\
\text { signaling } \\
\text { pathway }\end{array}$ & $\begin{array}{l}\text { Regulates proliferation, } \\
\text { survival and effector } \\
\text { functions of CD } 8+T \text { cells } \\
\text { by modulating Bcl } 2111 \\
\text { expression and PI3K-AKT } \\
\text { signaling pathway }\end{array}$ & (94) \\
\hline
\end{tabular}


TABLE 2 | Continued

\begin{tabular}{|c|c|c|c|c|c|c|c|c|}
\hline IncRNA & $\begin{array}{l}\text { Expression } \\
\text { pattern }\end{array}$ & Disease & Sample & Cell line & Interaction & $\begin{array}{l}\text { Signaling } \\
\text { pathway }\end{array}$ & Function & Reference \\
\hline & & & $\begin{array}{l}\text { TgCD4-Cre (CD4-cre), } \\
\text { and Tg(TcrLCMV) (P14) } \\
\text { mice }\end{array}$ & & & & & \\
\hline$R P 11-340 F 14.6$ & $\begin{array}{l}\text { Upregulated (in } \\
\text { JIA patients) }\end{array}$ & $\begin{array}{l}\text { Juvenile } \\
\text { idiopathic } \\
\text { arthritis (JIA) }\end{array}$ & $\begin{array}{l}\text { Blood samples from JIA } \\
\text { and healthy controls }\end{array}$ & T cell & P2X7R & - & $\begin{array}{l}\text { Increased Th17 } \\
\text { differentiation and inhibited } \\
\text { Treg distribution by binding } \\
\text { to P2X7R and inducing its } \\
\text { expression }\end{array}$ & (95) \\
\hline MALAT1 & - & Asthma & $\begin{array}{l}\text { Blood samples from } \\
772 \text { asthma patients } \\
\text { and } 441 \text { healthy } \\
\text { controls }\end{array}$ & CD4+ T cells & $\begin{array}{l}\operatorname{miR}-155 \\
\text { CTLA4 }\end{array}$ & - & $\begin{array}{l}\text { Regulated Th1/Th2 ratio by } \\
\text { sponging miR-155 and } \\
\text { modulating expression of } \\
\text { CTLA4 }\end{array}$ & (79) \\
\hline MEG3 & $\begin{array}{l}\text { Upregulated (in } \\
\text { CD4 }+T \text { cells of } \\
\text { patients with } \\
\text { asthma) }\end{array}$ & Asthma & $\begin{array}{l}\text { Blood samples from } 52 \\
\text { asthma patients and } 45 \\
\text { healthy controls }\end{array}$ & CD4 + T cells & $\begin{array}{l}\operatorname{miR}-17 \downarrow \\
\text { ROR } \gamma t\end{array}$ & - & $\begin{array}{l}\text { Elevated proportion of } \\
\text { Th17 cells and regulated } \\
\text { Treg/Th17 ratio by } \\
\text { sponging miR-17 and } \\
\text { upregulating } \mathrm{ROR} \text {. }\end{array}$ & $(80)$ \\
\hline MEG3 & $\begin{array}{l}\text { Downregulated } \\
\text { (in CD4 }+T \\
\text { cells of AA } \\
\text { patients) }\end{array}$ & $\begin{array}{l}\text { Aplastic } \\
\text { anemia (AA) }\end{array}$ & $\begin{array}{l}\text { Blood samples from } 15 \\
\text { AA patients and } 10 \\
\text { healthy controls }\end{array}$ & CD4+T cell & $\begin{array}{l}\text { miR-23a, } \\
\text { TIGIT }\end{array}$ & - & $\begin{array}{l}\text { Its overexpression } \\
\text { decreased proliferation of } \\
\text { CD4+T cell and inhibited } \\
\text { Th1 and Th17 } \\
\text { differentiation by absorbing } \\
\text { miR-23a and modulating } \\
\text { expression of TIGIT }\end{array}$ & (81) \\
\hline DQ786243 & $\begin{array}{l}\text { Upregulated (in } \\
\text { CD4+ cells of } \\
\text { OLP patients) }\end{array}$ & $\begin{array}{l}\text { Oral lichen } \\
\text { planus (OLP) }\end{array}$ & $\begin{array}{l}\text { Blood samples from } 10 \\
\text { OLP patients and } 10 \\
\text { healthy volunteers }\end{array}$ & CD4+ T cell & $\begin{array}{l}\operatorname{miR}-146 a \\
\text { Foxp3 }\end{array}$ & $\begin{array}{l}\mathrm{NF}-\kappa \mathrm{B} \\
\text { signaling } \\
\text { pathway }\end{array}$ & $\begin{array}{l}\text { Its overexpression } \\
\text { increased Treg cells } \\
\text { percentage and Foxp3 } \\
\text { expression and promoted } \\
\text { suppressive function of } \\
\text { these cells by modulating } \\
\text { Foxp3-miR-146a-NF-kB } \\
\text { axis }\end{array}$ & (90) \\
\hline AW112010 & $\begin{array}{l}\text { Upregulated (in } \\
\text { activated CD4+ } \\
\text { T cells) }\end{array}$ & - & Female C57BL/6J mice & CD4+ T cells & KDM5A & - & $\begin{array}{l}\text { Induces differentiation of } \\
\text { inflammatory T cells } \\
\text { through inhibiting } \\
\text { expression of IL-10 via } \\
\text { interacting with KDM5A } \\
\text { and histone demethylation }\end{array}$ & (96) \\
\hline GAS5 & $\begin{array}{l}\text { Downregulated } \\
\text { (in CD4+ T } \\
\text { cells of HIV } \\
\text { infected } \\
\text { patients) }\end{array}$ & AIDS & $\begin{array}{l}\text { Blood samples from } \\
142 \text { HIV infected } \\
\text { patients and } 58 \text { healthy } \\
\text { controls }\end{array}$ & CD4+ T cells & - & - & $\begin{array}{l}\text { Regulated apoptosis rate } \\
\text { and function of CD4+ T } \\
\text { cells during HIV infection } \\
\text { by modulating miR-21 }\end{array}$ & (97) \\
\hline LINC00176 & $\begin{array}{l}\text { Upregulated (in } \\
\text { CD4+T cells of } \\
\text { patients with } \\
\text { SLE) }\end{array}$ & $\begin{array}{l}\text { Systemic lupus } \\
\text { erythematosus } \\
\text { (SLE) }\end{array}$ & $\begin{array}{l}\text { Blood samples from } \\
\text { SLE patients and } \\
\text { healthy individuals }\end{array}$ & CD4+ T cells & WIF1 & $\begin{array}{l}\text { WNT5a } \\
\text { signaling } \\
\text { pathway }\end{array}$ & $\begin{array}{l}\text { Raised proliferation and } \\
\text { adhesion of CD4+T cells } \\
\text { by reducing WIF1 levels } \\
\text { and WNT5a pathway } \\
\text { activation }\end{array}$ & (98) \\
\hline IncRNA028466 & $\begin{array}{l}\text { Downregulated } \\
\text { (in CD4+ T } \\
\text { cells of mice } \\
\text { immunized with } \\
\text { rEg.P29 } \\
\text { antigen) }\end{array}$ & - & Female BALB/c mic & $\begin{array}{l}\text { CD4+ T cell, } \\
\text { CD8+ T cell }\end{array}$ & - & - & $\begin{array}{l}\text { Implicated in regulation of } \\
\text { cytokine expression from } \\
\text { CD4+ T cells }\end{array}$ & (99) \\
\hline $\begin{array}{l}\text { NONHSAT196558.1 } \\
\text { (TANCR) }\end{array}$ & - & - & $\begin{array}{l}\text { Blood samples normal } \\
\text { volunteers }\end{array}$ & $\begin{array}{l}\text { Primary } \gamma \delta \mathrm{T} \\
\text { cells, Jurkat } \\
\text { cells }\end{array}$ & TRAIL & - & $\begin{array}{l}\text { Increased activation and } \\
\text { cytotoxicity of } \gamma \delta \text { T cells by } \\
\text { modulating expression of } \\
\text { TRAIL in cis manner }\end{array}$ & $(100)$ \\
\hline Dreg1 & - & - & Male C57BL/6 mice & $\begin{array}{l}\text { splenic CD4+ } \\
\text { T cells from } \\
\text { mice and } \\
\text { human }\end{array}$ & Gata3 & - & $\begin{array}{l}\text { Its expression was } \\
\text { associated with expression } \\
\text { of Gata3 during Th2 } \\
\text { differentiation and }\end{array}$ & $(101)$ \\
\hline
\end{tabular}


TABLE 2 | Continued

\begin{tabular}{|c|c|c|c|c|c|c|c|c|}
\hline IncRNA & $\begin{array}{c}\text { Expression } \\
\text { pattern }\end{array}$ & Disease & Sample & Cell line & Interaction & $\begin{array}{l}\text { Signaling } \\
\text { pathway }\end{array}$ & Function & Referenc \\
\hline & & & & & & & $\begin{array}{l}\text { regulated Gata3 } \\
\text { expression during } \\
\text { development of immune } \\
\text { system }\end{array}$ & \\
\hline Gm15575 & $\begin{array}{l}\text { Upregulated (in } \\
\text { Th17 cells and } \\
\text { spleen tissues } \\
\text { of EAE mice) }\end{array}$ & $\begin{array}{l}\text { Multiple } \\
\text { sclerosis (MS) }\end{array}$ & C57BL/6 mice & CD4+ T cells & $\begin{array}{l}\text { miR-686, } \\
\text { CCL7 }\end{array}$ & - & $\begin{array}{l}\text { Promoted Th17 } \\
\text { differentiation by sponging } \\
\text { miR- } 686 \text { and upregulating } \\
\text { expression of CCL7 }\end{array}$ & (102) \\
\hline IncDDIT4 & $\begin{array}{l}\text { Upregulated (in } \\
\text { CD4+ T cells } \\
\text { and PBMCs of } \\
\text { patients with } \\
\text { MS) }\end{array}$ & $\begin{array}{l}\text { Multiple } \\
\text { sclerosis (MS) }\end{array}$ & $\begin{array}{l}\text { Blood samples from } 36 \\
\text { MS patients and } 26 \\
\text { healthy controls }\end{array}$ & $\begin{array}{l}\text { naive } \mathrm{CD} 4+\mathrm{T} \\
\text { cells }\end{array}$ & DDIT4 & $\begin{array}{l}\text { DDIT4/ } \\
\text { mTOR } \\
\text { Pathway }\end{array}$ & $\begin{array}{l}\text { Suppressed Th17 } \\
\text { differentiation by targeting } \\
\text { DDIT4 and inhibiting } \\
\text { DDIT4/mTOR signaling }\end{array}$ & (103) \\
\hline linc-MAF-4 & $\begin{array}{l}\text { Upregulated (in } \\
\text { PBMCs of } \\
\text { patients with } \\
\text { MS) }\end{array}$ & $\begin{array}{l}\text { Multiple } \\
\text { sclerosis (MS) }\end{array}$ & $\begin{array}{l}\text { Blood samples from } 34 \\
\text { MS patients and } 26 \\
\text { healthy subjects }\end{array}$ & $\begin{array}{l}\text { Naive CD4+ } \\
\text { T cells }\end{array}$ & MAF & - & $\begin{array}{l}\text { Suppressed Th2 } \\
\text { differentiation and } \\
\text { promoted Th17 } \\
\text { differentiation by inhibiting } \\
\text { MAF expression }\end{array}$ & $(104)$ \\
\hline$N K I L A$ & $\begin{array}{l}\text { Upregulated (in } \\
\text { CTLs and TH1 } \\
\text { cells of patients } \\
\text { with breast and } \\
\text { lung cancer) }\end{array}$ & $\begin{array}{l}\text { Non-small cell } \\
\text { lung cancer } \\
\text { (NSCLC) and } \\
\text { breast cancer }\end{array}$ & $\begin{array}{l}\text { Tissue samples and } \\
\text { blood samples from } \\
576 \text { h invasive breast } \\
\text { carcinoma patients and } \\
256 \text { NSCLC patients, } \\
\text { blood samples from } \\
\text { healthy donors, } \\
\text { NOD.SCID mice }\end{array}$ & $\begin{array}{l}\text { CD8+ and } \\
\text { CD4+ T cells, } \\
\text { cytotoxic T } \\
\text { lymphocyte } \\
\text { (CTL), Th1, } \\
\text { Th2 and Treg }\end{array}$ & $N F-\kappa B$ & - & $\begin{array}{l}\text { Sensitized CTLs and Th1 } \\
\text { cells to activation-induced } \\
\text { cell death in tumor } \\
\text { microenvironment and } \\
\text { facilitated tumor immune } \\
\text { evasion through } \\
\text { suppression of NF-кB } \\
\text { activity }\end{array}$ & $(105)$ \\
\hline IFNA-AS1 & $\begin{array}{l}\text { Downregulated } \\
\text { (in PBMCs of } \\
\text { patients with } \\
\text { MG) }\end{array}$ & $\begin{array}{l}\text { Myasthenia } \\
\text { gravis (MG) }\end{array}$ & $\begin{array}{l}\text { Blood samples from } 32 \\
\text { MG patients and } 20 \\
\text { healthy volunteers, } \\
\text { female C57/BL6 mice }\end{array}$ & $\begin{array}{l}\text { CD4+ T cell, } \\
\text { Jurkat T cell }\end{array}$ & HLA-DRB1 & - & $\begin{array}{l}\text { Is implicated in regulation } \\
\text { of Th1/Treg cell } \\
\text { proliferation and activation } \\
\text { of CD } 4+T \text { cells by } \\
\text { influencing HLA-DRB1 }\end{array}$ & $(106)$ \\
\hline GATA3-AS1 & - & - & $\begin{array}{l}\text { Blood samples from } \\
\text { healthy volunteers }\end{array}$ & $\begin{array}{l}\text { Human } \\
\text { PBMC }\end{array}$ & GATA3 & - & $\begin{array}{l}\text { Regulated polarization of } \\
\text { Th2 cells by increasing } \\
\text { expression of GATA3 }\end{array}$ & $(107)$ \\
\hline
\end{tabular}

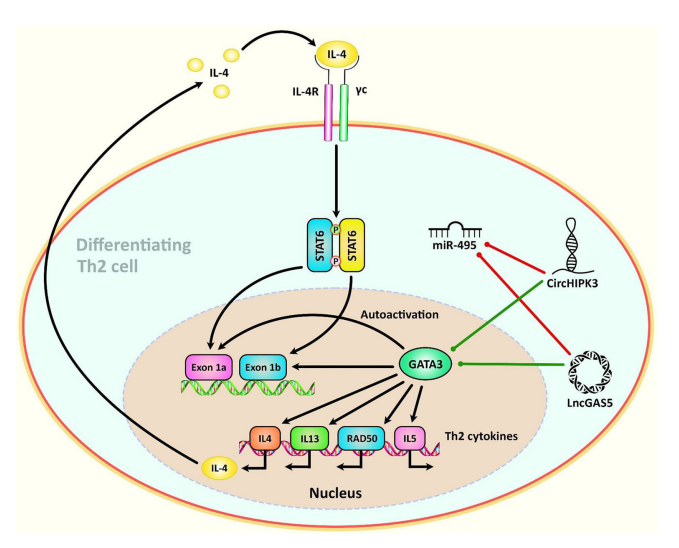

FIGURE 3 | A schematic diagram of the role of some ncRNAs in modulating the IL-4-STAT6-GATA3 axis in Th2-cell differentiation. Th2 cell differentiation requires considerable metabolic reprogramming. Upon encountering cognate antigen in the lymph node, naive CD4 T helper cells are differentiated into Th2 cells under the effect of the IL-4-STAT6-GATA3 axis. GATA3 could, in turn, alter the IL4- IL13-IL5 locus to generate a conformation that is reachable by different other transcription factors that are involved in triggering the differentiation of T cells into T H2 cells (117). Growing evidence has confirmed that the interactions between CircHIPK3, LncGAS5, and miR-495 could play a crucial role in the modulation of Th2 differentiation in allergic rhinitis (116). Green arrows indicate upregulation of target genes by ncRNAs (IncRNA, and circRNA), red arrows depict inhibitory effects of by these ncRNAs. 
TABLE 3 | CircRNAs and T cell regulation.

\begin{tabular}{|c|c|c|c|c|c|c|c|c|}
\hline circRNA & $\begin{array}{c}\text { Expression } \\
\text { pattern }\end{array}$ & Disease & Sample & $\begin{array}{l}\text { Cell } \\
\text { line }\end{array}$ & Interaction & $\begin{array}{l}\text { Signaling } \\
\text { pathway }\end{array}$ & Function & Reference \\
\hline circ_0001806 & $\begin{array}{l}\text { Downregulated } \\
\text { (in PBMCs of } \\
\text { CM patients) }\end{array}$ & $\begin{array}{l}\text { Cryptococcal } \\
\text { meningitis (CM) }\end{array}$ & $\begin{array}{l}\text { Blood samples from } 20 \\
\text { CM patients and } 18 \\
\text { healthy donors, female } \\
\text { C57BL/ } 6 \text { mice }\end{array}$ & $\begin{array}{l}\text { Jurkat } \\
\text { T, } \\
\text { CD3+ } \\
\text { T cells }\end{array}$ & $\begin{array}{l}\text { miR-126, } \\
\text { ADM }\end{array}$ & - & $\begin{array}{l}\text { Reduced apoptosis rate in T cells } \\
\text { by sponging miRNA-126 and } \\
\text { positive regulation of ADM }\end{array}$ & (111) \\
\hline hsa_circ_0045272 & $\begin{array}{l}\text { Downregulated } \\
\text { (in T cells of } \\
\text { SLE patients) }\end{array}$ & $\begin{array}{l}\text { Systemic lupus } \\
\text { erythematosus } \\
\text { (SLE) }\end{array}$ & $\begin{array}{l}\text { Blood samples from } 24 \\
\text { patients and } 12 \text { healthy } \\
\text { controls }\end{array}$ & $\begin{array}{l}293 T, \\
\text { Jurkat } \\
\text { cells }\end{array}$ & $\begin{array}{l}\text { hsa-miR- } \\
6127\end{array}$ & - & $\begin{array}{l}\text { Its knockdown resulted in } \\
\text { increased early apoptosis in } \mathrm{T} \\
\text { cells and elevated production of } \\
\text { IL-2 }\end{array}$ & $(112)$ \\
\hline hsa_circ_0012919 & $\begin{array}{l}\text { Upregulated (in } \\
\text { CD4+ T cells of } \\
\text { SLE patients) }\end{array}$ & SLE & $\begin{array}{l}\text { Blood samples from } 28 \\
\text { SLE patients and } 18 \\
\text { healthy controls }\end{array}$ & $\begin{array}{l}\text { CD4+ } \\
\text { T cells }\end{array}$ & $\begin{array}{l}\text { RNATES, } \\
\text { KLF13, } \\
\text { miR-125 }\end{array}$ & - & $\begin{array}{l}\text { Its downregulation led to } \\
\text { upregulation of DNMT1 and } \\
\text { decreased expression and } \\
\text { hypermethylation of CD11a and } \\
\text { CD70 in CD4+ T cells. }\end{array}$ & $(113)$ \\
\hline hsa_circ_0012919 & $\begin{array}{l}\text { Upregulated (in } \\
\text { CD4+ T cells of } \\
\text { SLE patients) }\end{array}$ & SLE & $\begin{array}{l}\text { Blood samples from } 20 \\
\text { SLE patients and } 12 \\
\text { healthy controls }\end{array}$ & $\begin{array}{l}\text { CD4+ } \\
\text { T cells }\end{array}$ & $\begin{array}{l}\text { miR-125a- } \\
3 p, \text { MDA5 }\end{array}$ & - & $\begin{array}{l}\text { Increases expression of MDA5 in } \\
\text { CD4+ T cells through } \\
\text { downregulating miR-125a-3p }\end{array}$ & $(114)$ \\
\hline Hsa_circ_0005519 & $\begin{array}{l}\text { Upregulated (in } \\
\text { CD4+ T cells } \\
\text { form patients } \\
\text { with asthma) }\end{array}$ & Asthma & $\begin{array}{l}\text { Blood samples from } 65 \\
\text { asthmatic patients and } 30 \\
\text { healthy individuals }\end{array}$ & $\begin{array}{l}\text { CD4+ } \\
\text { T cells }\end{array}$ & $\begin{array}{l}\text { hsa-let-7a- } \\
5 p\end{array}$ & - & $\begin{array}{l}\text { Augments expression of IL-13 } \\
\text { and IL- } 6 \text { by targeting hsa-let-7a- } \\
5 p \text { in CD4+ T cells }\end{array}$ & $(115)$ \\
\hline CirchIPK3 & $\begin{array}{l}\text { Upregulated (in } \\
\text { nasal mucosal } \\
\text { tissues of AR } \\
\text { patients) }\end{array}$ & $\begin{array}{l}\text { Allergic rhinitis } \\
(A R)\end{array}$ & $\begin{array}{l}\text { Blood samples and nasal } \\
\text { mucosa specimens from } \\
10 \text { AR patients and } 10 \\
\text { healthy controls, male } \\
\text { BALB/c mice }\end{array}$ & $\begin{array}{l}\text { CD4+ } \\
\text { T cells }\end{array}$ & $\begin{array}{l}\text { miR-495, } \\
\text { GATA-3 }\end{array}$ & - & $\begin{array}{l}\text { Promotes differentiation of CD4+ } \\
\text { T cells to Th2 by targeting miR- } \\
495 \text { and increasing expression of } \\
\text { GATA-3 }\end{array}$ & $(116)$ \\
\hline
\end{tabular}

and mRNAs in different stages of $\mathrm{T}$ cells development would help in recognition of role of each transcript in development of this group of blood cells. Further knock-in and knock-out studies in different disease conditions can help in identification of specific treatment strategies for related disorders.

\section{AUTHOR CONTRIBUTIONS}

SG-F, DB, and JK wrote the draft and revised it. MT and MP designed and supervised the study. OR and MT designed the figures and tables. All authors contributed to the article and approved the submitted version.

\section{REFERENCES}

1. Golubovskaya V, Wu L. Different Subsets of T Cells, Memory, Effector Functions, and CAR-T Immunotherapy. Cancers (Basel) (2016) 8(3):36. doi: $10.3390 /$ cancers 8030036

2. Pereira MS, Alves I, Vicente M, Campar A, Silva MC, Padrão NA, et al. Glycans as Key Checkpoints of T Cell Activity and Function. Front Immunol (2018) 9(2754). doi: 10.3389/fimmu.2018.02754

3. Raphael I, Nalawade S, Eagar TN, Forsthuber TG. T Cell Subsets and Their Signature Cytokines in Autoimmune and Inflammatory Diseases. Cytokine (2015) 74(1):5-17. doi: 10.1016/j.cyto.2014.09.011

4. Rudensky AY. Regulatory T Cells and Foxp3. Immunol Rev (2011) 241 (1):260-8. doi: 10.1111/j.1600-065X.2011.01018.x

5. Feng Y, Arvey A, Chinen T, van der Veeken J, Gasteiger G, Rudensky AY. Control of the Inheritance of Regulatory T Cell Identity by a Cis Element in the Foxp3 Locus. Cell (2014) 158(4):749-63. doi: 10.1016/j.cell.2014.07.031

6. Best JA, Blair DA, Knell J, Yang E, Mayya V, Doedens A, et al. Transcriptional Insights Into the CD8(+) T Cell Response to Infection and Memory T Cell Formation. Nat Immunol (2013) 14(4):404-12. doi: 10.1038/ni.2536

7. Smolle MA, Calin HN, Pichler M, Calin GA. Noncoding RNAs and Immune Checkpoints-Clinical Implications as Cancer Therapeutics. FEBS J (2017) 284(13):1952-66. doi: 10.1111/febs.14030

8. Salmena L, Poliseno L, Tay Y, Kats L, Pandolfi PP. A ceRNA Hypothesis: The Rosetta Stone of a Hidden RNA Language? Cell (2011) 146(3):353-8. doi: 10.1016/j.cell.2011.07.014

9. Macfarlane L-A, Murphy PR. MicroRNA: Biogenesis, Function and Role in Cancer. Curr Genomics (2010) 11(7):537-61. doi: 10.2174/ 138920210793175895

10. Pichler M, Calin GA. MicroRNAs in Cancer: From Developmental Genes in Worms to Their Clinical Application in Patients. Br J Cancer (2015) 113 (4):569-73. doi: 10.1038/bjc.2015.253

11. Pichler M, Stiegelbauer V, Vychytilova-Faltejskova P, Ivan C, Ling H, Winter E, et al. Genome-Wide miRNA Analysis Identifies miR-188-3p as a Novel Prognostic Marker and Molecular Factor Involved in Colorectal Carcinogenesis. Clin Cancer Res an Off J Am Assoc Cancer Res (2017) 23 (5):1323-33. doi: 10.1158/1078-0432.CCR-16-0497

12. Gagnon JD, Kageyama R, Shehata HM, Fassett MS, Mar DJ, Wigton EJ, et al. miR-15/16 Restrain Memory T Cell Differentiation, Cell Cycle, and Survival. Cell Rep (2019) 28(8):2169-81. e4. doi: 10.1016/j.celrep.2019. 07.064

13. Lu Z, Liu J, Liu X, Huang E, Yang J, Qian J, et al. MicroRNA 15a/16-1 Suppresses Aryl Hydrocarbon Receptor-Dependent Interleukin-22 Secretion in CD4+ T Cells and Contributes to Immune-Mediated Organ Injury. Hepatology (2018) 67(3):1027-40. doi: 10.1002/hep.29573

14. Zhu Y, Zhang S, Li Z, Wang H, Li Z, Hu Y, et al. miR-125b-5p and miR-99a$5 p$ Downregulate Human $\gamma \delta$ T-Cell Activation and Cytotoxicity. Cell Mol Immunol (2019) 16(2):112-25. doi: 10.1038/cmi.2017.164

15. Fan Z-D, Cao Q, Huang N, Ma L, Ma H-H, Zhang Y-Y, et al. MicroRNA125b Regulates Th17/Treg Cell Differentiation and is Associated With Juvenile Idiopathic Arthritis. World J Pediatr (2020) 16(1):99-110. doi: 10.1007/s12519-019-00265-Z 
16. Berg JL, Perfler B, Hatzl S, Mayer MC, Wurm S, Uhl B, et al. Micro-RNA125a Mediates the Effects of Hypomethylating Agents in Chronic Myelomonocytic Leukemia. Clin Epigenet (2021) 13(1):1. doi: 10.1186/ s13148-020-00979-2

17. Zhu S, Zhang X, Guan H, Huang F, Wu L, Hou D, et al. miR-140-5p Regulates T Cell Differentiation and Attenuates Experimental Autoimmune Encephalomyelitis by Affecting CD4+ T Cell Metabolism and DNA Methylation. Int Immunopharmacol (2019) 75:105778. doi: 10.1016/ j.intimp.2019.105778

18. Yang P, Zhang M, Wang X, Xu A-L, Shen M, Jiang B, et al. MicroRNA Let7g-5p Alleviates Murine Collagen-Induced Arthritis by Inhibiting Th17 Cell Differentiation. Biochem Pharmacol (2020) 174:113822. doi: 10.1016/ j.bcp.2020.113822

19. Li Z-H, Wang Y-F, He D-D, Zhang X-M, Zhou Y-L, Yue H, et al. Let-7f-5p Suppresses Th17 Differentiation via Targeting STAT3 in Multiple Sclerosis. Aging (Albany NY) (2019) 11(13):4463. doi: 10.18632/aging.102093

20. Wang J, Wang X, Wang L, Sun C, Xie C, Li Z. MiR-Let-7d-3p Regulates IL-17 Expression Through Targeting AKT1/mTOR Signaling in CD4+ T Cells. In Vitro Cell Dev Biol-Animal (2020) 56(1):67-74. doi: 10.1007/s11626-019-00409-5

21. Wang H, Flach H, Onizawa M, Wei L, McManus MT, Weiss A. Negative Regulation of Hifla Expression and TH 17 Differentiation by the HypoxiaRegulated microRNA miR-210. Nat Immunol (2014) 15(4):393-401. doi: 10.1038/ni.2846

22. Wu R, Zeng J, Yuan J, Deng X, Huang Y, Chen L, et al. MicroRNA-210 Overexpression Promotes Psoriasis-Like Inflammation by Inducing Th1 and Th17 Cell Differentiation. J Clin Invest (2018) 128(6):2551-68. doi: 10.1172/ JCI97426

23. Lim SP, Ioannou N, Ramsay AG, Darling D, Gäken J, Mufti GJ. miR-181cBRK1 Axis Plays a Key Role in Actin Cytoskeleton-Dependent T Cell Function. J Leukocyte Biol (2018) 103(5):855-66. doi: 10.1002/JLB.1A0817-325RR

24. Amado T, Amorim A, Enguita FJ, Romero PV, Inácio D, de Miranda MP, et al. MicroRNA-181a Regulates IFN- $\gamma$ Expression in Effector CD8+ T Cell Differentiation. J Mol Med (2020) 98(2):309-20. doi: 10.1007/s00109-01901865-y

25. Zeng Q, Liu W, Luo R, Lu G. MicroRNA-181a and microRNA-155 are Involved in the Regulation of the Differentiation and Function of Regulatory T Cells in Allergic Rhinitis Children. Pediatr Allergy Immunol (2019) 30 (4):434-42. doi: 10.1111/pai.13038

26. Cargnello M, Roux PP. Activation and Function of the MAPKs and Their Substrates, the MAPK-Activated Protein Kinases. Microbiol Mol Biol Rev (2011) 75(1):50-83. doi: 10.1128/MMBR.00031-10

27. Kawashima N, Nakayama K, Itoh K, Itoh T, Ishikawa M, Biju V. Reversible Dimerization of EGFR Revealed by Single-Molecule Fluorescence Imaging Using Quantum Dots. Chem-A Eur J (2010) 16(4):1186-92. doi: 10.1002/ chem. 200902963

28. Sun J, Nan G. The Extracellular Signal-Regulated Kinase 1/2 Pathway in Neurological Diseases: A Potential Therapeutic Target. Int J Mol Med (2017) 39(6):1338-46. doi: 10.3892/ijmm.2017.2962

29. Baranova J, Dragunas G, Botellho MC, Ayub ALP, Bueno-Alves R, Alencar RR, et al. Autism Spectrum Disorder: Signaling Pathways and Prospective Therapeutic Targets. Cell Mol Neurobiol (2021) 41:619-49. doi: 10.1007/ s10571-020-00882-7

30. Yu JS, Cui W. Proliferation, Survival and Metabolism: The Role of PI3K/ AKT/mTOR Signalling in Pluripotency and Cell Fate Determination. Development (2016) 143(17):3050-60. doi: 10.1242/dev.137075

31. Magnuson B, Ekim B, Fingar DC. Regulation and Function of Ribosomal Protein S6 Kinase (S6K) Within mTOR Signalling Networks. Biochem J (2012) 441(1):1-21. doi: 10.1042/BJ20110892

32. Yi H, Bai Y, Zhu X, Zhao L, Wu X, Buch S, et al. IL-17A Induces MIP-1 $\alpha$ Expression in Primary Astrocytes via Src/MAPK/PI3K/NF-kB Pathways: Implications for Multiple Sclerosis. J Neuroimmune Pharmacol (2014) 9 (5):629-41.

33. Owen KL, Brockwell NK, Parker BS. JAK-STAT Signaling: A Double-Edged Sword of Immune Regulation and Cancer Progression. Cancers (Basel) (2019) 11(12):2002.

34. Ye L, Shi H, Yu C, Fu J, Chen C, Wu S, et al. LncRNA Neat1 Positively Regulates MAPK Signaling and is Involved in the Pathogenesis of Sjögren's Syndrome. Int Immunopharmacol (2020) 88:106992.
35. Xia Z, Meng F, Liu Y, Fang Y, Wu X, Zhang C, et al. Decreased MiR-128-3p Alleviates the Progression of Rheumatoid Arthritis by Up-Regulating the Expression of TNFAIP3. Biosci Rep (2018) 38(4):BSR20180540. doi: 10.1042/BSR20180540

36. Thiel J, Alter C, Luppus S, Eckstein A, Tan S, Führer D, et al. MicroRNA-183 and microRNA-96 are Associated With Autoimmune Responses by Regulating T Cell Activation. J Autoimmun (2019) 96:94-103. doi: 10.1016/j.jaut.2018.08.010

37. Zhang L, Sun P, Zhang Y, Xu Y, Sun Y. miR-182-5p Inhibits the Pathogenic Th17 Response in Experimental Autoimmune Uveitis Mice via Suppressing TAF15. Biochem Biophys Res Commun (2020) 529(3):784-92. doi: 10.1016/ j.bbrc.2020.06.073

38. Wang M, Ji Y, Song Z, Ma X, Zou Y, Li X. Knockdown of lncRNA ZFAS1 Inhibits Progression of Nasopharyngeal Carcinoma by Sponging miR-135a. Neoplasma (2019) 66(6):939-45. doi: 10.4149/neo_2018_181213N963

39. Pan J, Zhang D, Zhang J, Qin P, Wang J. LncRNA RMRP Silence Curbs Neonatal Neuroblastoma Progression by Regulating microRNA-206/Tachykinin-1 Receptor Axis via Inactivating Extracellular Signal-Regulated Kinases. Cancer Biol Ther (2019) 20(5):653-65. doi: 10.1080/15384047.2018.1550568

40. Zitzer NC, Snyder K, Meng X, Taylor PA, Efebera YA, Devine SM, et al. MicroRNA-155 Modulates Acute Graft-Versus-Host Disease by Impacting T Cell Expansion, Migration, and Effector Function. J Immunol (2018) 200 (12):4170-9. doi: 10.4049/jimmunol.1701465

41. Goncalves-Alves E, Saferding V, Schliehe C, Benson R, Kurowska-Stolarska M, Brunner JS, et al. MicroRNA-155 Controls T Helper Cell Activation During Viral Infection. Front Immunol (2019) 10:1367. doi: 10.3389/ fimmu.2019.01367

42. Lv M, Li Z, Liu J, Lin F, Zhang Q, Li Z, et al. MicroRNA-155 Inhibits the Proliferation of CD8+ T Cells via Upregulating Regulatory T Cells in Vitiligo. Mol Med Rep (2019) 20(4):3617-24. doi: 10.3892/mmr.2019.10607

43. Qiu C, Ma J, Wang M, Zhang Q, Li Y. MicroRNA-155 Deficiency in CD8+ T Cells Inhibits its Anti-Glioma Immunity by Regulating FoxO3a. Eur Rev Med Pharmacol Sci (2019) 23(6):2486-96. doi: 10.26355/ eurrev_201903_17396

44. Zhang T, Zhang Z, Li F, Ping Y, Qin G, Zhang C, et al. miR-143 Regulates Memory $\mathrm{T}$ Cell Differentiation by Reprogramming T Cell Metabolism. J Immunol (2018) 201(7):2165-75. doi: 10.4049/jimmunol.1800230

45. Wu Y, Schutt S, Paz K, Zhang M, Flynn RP, Bastian D, et al. MicroRNA-1792 is Required for T-Cell and B-Cell Pathogenicity in Chronic Graft-VersusHost Disease in Mice. Blood (2018) 131(17):1974-86. doi: 10.1182/blood2017-06-789321

46. Bolandi Z, Mokhberian N, Eftekhary M, Sharifi K, Soudi S, Ghanbarian H, et al. Adipose Derived Mesenchymal Stem Cell Exosomes Loaded With miR10a Promote the Differentiation of Th17 and Treg From Naive CD4+ T Cell. Life Sci (2020) 259:118218. doi: 10.1016/j.lfs.2020.118218

47. You G, Cao H, Yan L, He P, Wang Y, Liu B, et al. MicroRNA-10a-3p Mediates Th17/Treg Cell Balance and Improves Renal Injury by Inhibiting REG3A in Lupus Nephritis. Int Immunopharmacol (2020) 88:106891. doi: 10.1016/j.intimp.2020.106891

48. Han W, Li N, Liu J, Sun Y, Yang X, Wang Y. MicroRNA-26b-5p Enhances T Cell Responses by Targeting PIM-2 in Hepatocellular Carcinoma. Cell signalling (2019) 59:182-90. doi: 10.1016/j.cellsig.2018.11.011

49. Scherm MG, Serr I, Zahm AM, Schug J, Bellusci S, Manfredini R, et al. Mirna142-3p Targets Tet2 and Impairs Treg Differentiation and Stability in Models of Type 1 Diabetes. Nat Commun (2019) 10(1):1-15. doi: 10.1038/ s41467-019-13587-3

50. Lu Y, Gao J, Zhang S, Gu J, Lu H, Xia Y, et al. miR-142-3p Regulates Autophagy by Targeting ATG16L1 in Thymic-Derived Regulatory T Cell (Ttreg). Cell Death Dis (2018) 9(3):1-10. doi: 10.1038/s41419-018-0298-2

51. Gao ZF, Ji XL, Gu J, Wang XY, Ding L, Zhang H. microRNA-107 Protects Against Inflammation and Endoplasmic Reticulum Stress of Vascular Endothelial Cells via KRT1-Dependent Notch Signaling Pathway in a Mouse Model of Coronary Atherosclerosis. J Cell Physiol (2019) 234 (7):12029-41. doi: 10.1002/jcp.27864

52. Hart M, Walch-Rückheim B, Friedmann KS, Rheinheimer S, Tänzer T, Glombitza B, et al. miR-34a: A New Player in the Regulation of T Cell Function by Modulation of NF-kb Signaling. Cell Death Dis (2019) 10(2):114. doi: 10.1038/s41419-018-1295-1 
53. Ping W, Senyan H, Li G, Yan C, Long L. Increased Lactate in Gastric Cancer Tumor-Infiltrating Lymphocytes is Related to Impaired T Cell Function Due to miR-34a Deregulated Lactate Dehydrogenase a. Cell Physiol Biochem (2018) 49(2):828-36. doi: 10.1159/000493110

54. Ge B, Liu H, Liang Q, Shang L, Wang T, Ge S. Oxytocin Facilitates the Proliferation, Migration and Osteogenic Differentiation of Human Periodontal Stem Cells In Vitro. Arch Oral Biol (2019) 99:126-33. doi: 10.1016/j.archoralbio.2019.01.007

55. Chu F, Hu Y, Zhou Y, Guo M, Lu J, Zheng W, et al. MicroRNA-126 Deficiency Enhanced the Activation and Function of CD4+ T Cells by Elevating IRS-1 Pathway. Clin Exp Immunol (2018) 191(2):166-79. doi: 10.1111/cei.13067

56. Yang X, He Q, Guo Z, Xiong F, Li Y, Pan Y, et al. MicroRNA-425 Facilitates Pathogenic Th17 Cell Differentiation by Targeting Forkhead Box O1 (Foxol) and is Associated With Inflammatory Bowel Disease. Biochem Biophys Res Commun (2018) 496(2):352-8. doi: 10.1016/j.bbrc.2018.01.055

57. Shi Y, Dai S, Qiu C, Wang T, Zhou Y, Xue C, et al. MicroRNA-219a-5p Suppresses Intestinal Inflammation Through Inhibiting Th1/Th17Mediated Immune Responses in Inflammatory Bowel Disease. Mucosal Immunol (2020) 13(2):303-12. doi: 10.1038/s41385-019-0216-7

58. Fang Y, Chen S, Liu Z, Ai W, He X, Wang L, et al. Endothelial Stem Cells Attenuate Cardiac Apoptosis via Downregulating Cardiac microRNA-146a in a Rat Model of Coronary Heart Disease. Exp Ther Med (2018) 16(5):424652. doi: 10.3892/etm.2018.6702

59. Huo J, Liu T, Li F, Song X, Hou X. MicroRNA-21-5p Protects Melanocytes via Targeting STAT3 and Modulating Treg/Teff Balance to Alleviate Vitiligo. Mol Med Rep (2021) 23(1):1-. doi: 10.3892/mmr.2020.11689

60. Wei Y, Chen S, Sun D, Li X, Wei R, Li X, et al. miR-223-3p Promotes Autoreactive Th17 Cell Responses in Experimental Autoimmune Uveitis (EAU) by Inhibiting Transcription Factor FOXO3 Expression. FASEB J (2019) 33(12):13951-65. doi: 10.1096/fj.201901446R

61. Li C, Wang X, Yuan F, Zhao Z, Zhang B, Zhang J, et al. MiR-669b-3p Regulates CD4+ T Cell Function by Down-Regulating Indoleamine-2, 3Dioxygenase. Transplant Immunol (2020) 62:101320. doi: 10.1016/ j.trim.2020.101320

62. Schmolka N, Papotto PH, Romero PV, Amado T, Enguita FJ, Amorim A, et al. MicroRNA-146a Controls Functional Plasticity in $\gamma \delta \mathrm{T}$ Cells by Targeting NOD1. Sci Immunol (2018) 3(23). doi: 10.1126/ sciimmunol.aao1392

63. Zhang J, Chen G-Y, Wang F, Zhou G. MiR-29b Interacts With IFN- $\gamma$ and Induces DNA Hypomethylation in CD4+ T Cells of Oral Lichen Planus. Int J Biol Macromolecules (2020) 147:1248-54. doi: 10.1016/j.ijbiomac.2019.09.252

64. Huang R, Chen X, Long Y, Chen R. MiR-31 Promotes Th22 Differentiation Through Targeting Bach2 in Coronary Heart Disease. Biosci Rep (2019) 39 (9). doi: 10.1042/BSR20190986

65. Cao Y-L, Dong W, Li Y-Z, Han W. MicroRNA-653 Inhibits Thymocyte Proliferation and Induces Thymocyte Apoptosis in Mice With Autoimmune Myasthenia Gravis by Downregulating TRIM9. Neuroimmunomodulation (2019) 26(1):7-18. doi: 10.1159/000494802

66. Zhang Z, Liu J, Wang Y, Tan X, Zhao W, Xing X, et al. Phosphatidylinositol 3 -Kinase $\beta$ and $\beta$ Isoforms Play Key Roles in Metastasis of Prostate Cancer DU145 Cells. The FASEB Journal (2018) 32(11):5967-75. doi: 10.1096/ fj.201800183R

67. Gao L, Zeng H, Zhang T, Mao C, Wang Y, Han Z, et al. MicroRNA-21 Deficiency Attenuated Atherogenesis and Decreased Macrophage Infiltration by Targeting Dusp-8. Atherosclerosis (2019) 291:78-86. doi: 10.1016/j.atherosclerosis.2019.10.003

68. Jin L-W, Ye H-Y, Xu X-Y, Zheng Y, Chen Y. MiR-133a/133b Inhibits Treg Differentiation in IgA Nephropathy Through Targeting FOXP3. Biomed Pharmacother (2018) 101:195-200. doi: 10.1016/j.biopha.2018.02.022

69. Ling H, Vincent K, Pichler M, Fodde R, Berindan-Neagoe I, Slack FJ, et al. Junk DNA and the Long non-Coding RNA Twist in Cancer Genetics. Oncogene (2015) 34(39):5003-11. doi: 10.1038/onc.2014.456

70. Seles M, Hutterer GC, Kiesslich T, Pummer K, Berindan-Neagoe I, Perakis S, et al. Current Insights Into Long Non-Coding RNAs in Renal Cell Carcinoma. Int J Mol Sci (2016) 17(4):573. doi: 10.3390/ijms17040573

71. Fang Y, Fullwood MJ. Roles, Functions, and Mechanisms of Long nonCoding RNAs in Cancer. Genomics Proteomics Bioinf (2016) 14(1):42-54. doi: $10.1016 /$ j.gpb.2015.09.006
72. Rankin CR, Shao L, Elliott J, Rowe L, Patel A, Videlock E, et al. The IBDAssociated Long Noncoding RNA IFNG-AS1 Regulates the Balance Between Inflammatory and Anti-Inflammatory Cytokine Production After T-Cell Stimulation. Am J Physiol-Gastrointestinal Liver Physiol (2020) 318(1):G3440. doi: 10.1152/ajpgi.00232.2019

73. Nie J, Zhao Q. Lnc-ITSN1-2, Derived From RNA Sequencing, Correlates With Increased Disease Risk, Activity and Promotes CD4+ T Cell Activation, Proliferation and Th1/Th17 Cell Differentiation by Serving as a ceRNA for IL-23R via Sponging miR-125a in Inflammatory Bowel Disease. Front Immunol (2020) 11:852. doi: 10.3389/fimmu.2020.00852

74. Prinz F, Kapeller A, Pichler M, Klec C. The Implications of the Long NonCoding RNA NEAT1 in Non-Cancerous Diseases. Int J Of Mol Sci (2019) 20 (3):627. doi: 10.3390/ijms20030627

75. Klec C, Prinz F, Pichler M. Involvement of the Long Noncoding RNA NEAT1 in Carcinogenesis. Mol Oncol (2019) 13(1):46-60. doi: 10.1002/ 1878-0261.12404

76. Chen JX, Xu X, Zhang S. Silence of Long Noncoding RNA NEAT1 Exerts Suppressive Effects on Immunity During Sepsis by Promoting microRNA125-Dependent MCEMP1 Downregulation. IUBMB Life (2019) 71(7):95668. doi: 10.1002/iub.2033

77. Shui X, Chen S, Lin J, Kong J, Zhou C, Wu J. Knockdown of IncRNA NEAT1 Inhibits Th17/CD4+ T Cell Differentiation Through Reducing the STAT3 Protein Level. J Cell Physiol (2019) 234(12):22477-84. doi: $10.1002 /$ jcp. 28811

78. Wu L, Zhu X, Song Z, Chen D, Guo M, Liang J, et al. Long non-Coding RNA HOXA-AS2 Enhances the Malignant Biological Behaviors in Glioma by Epigenetically Regulating RND3 Expression. Onco Targets Ther (2019) 12:9407. doi: 10.2147/OTT.S225678

79. Liang Z, Tang F. The Potency of lncRNA MALAT1/miR-155/CTLA4 Axis in Altering Th1/Th2 Balance of Asthma. Biosci Rep (2020) 40(2):BSR20190397. doi: 10.1042/BSR20190397

80. Qiu Y-Y, Wu Y, Lin M-J, Bian T, Xiao Y-L, Qin C. LncRNA-MEG3 Functions as a Competing Endogenous RNA to Regulate Treg/Th17 Balance in Patients With Asthma by Targeting microRNA-17/Ror $\gamma \mathrm{t}$ Biomed Pharmacother (2019) 111:386-94. doi: 10.1016/j.biopha.2018.12.080

81. Wang J, Liu X, Hao C, Lu Y, Duan X, Liang R, et al. MEG3 Modulates TIGIT Expression and CD4+ T Cell Activation Through Absorbing miR-23a. Mol Cell Biochem (2019) 454(1):67-76. doi: 10.1007/s11010-018-3453-2

82. Villarino AV, Kanno Y, Ferdinand JR, O'Shea JJ. Mechanisms of Jak/STAT Signaling in Immunity and Disease. J Immunol (2015) 194(1):21-7. doi: 10.4049/jimmunol.1401867

83. Shuai K, Liu B. Regulation of JAK-STAT Signalling in the Immune System. Nat Rev Immunol (2003) 3(11):900-11. doi: 10.1038/nri1226

84. Liu X, Wang J, Wang H, Yin G, Liu Y, Lei X, et al. REG3A Accelerates Pancreatic Cancer Cell Growth Under IL-6-Associated Inflammatory Condition: Involvement of a REG3A-JAK2/STAT3 Positive Feedback Loop. Cancer Lett (2015) 362(1):45-60. doi: 10.1016/j.canlet.2015.03.014

85. Tornatore L, Thotakura AK, Bennett J, Moretti M, Franzoso G. The Nuclear Factor Kappa B Signaling Pathway: Integrating Metabolism With Inflammation. Trends Cell Biol (2012) 22(11):557-66. doi: 10.1016/j.tcb.2012.08.001

86. Chen FE, Huang D-B, Chen Y-Q, Ghosh G. Crystal Structure of P50/P65 Heterodimer of Transcription Factor NF- $\mathrm{kb}$ Bound to DNA. Nature (1998) 391(6665):410-3. doi: 10.1038/34956

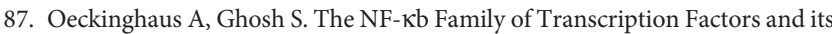
Regulation. Cold Spring Harbor Perspect In Biol (2009) 1(4):a000034. doi: 10.1101/cshperspect.a000034

88. Matsumoto I, Inoue A, Takai C, Umeda N, Tanaka Y, Kurashima Y, et al. Regulatory Roles of Tumor Necrosis Factor Alpha-Induced Proteins (TNFAIPs) 3 and 9 in Arthritis. Clin Immunol (2014) 153(1):73-8. doi: 10.1016/j.clim.2014.03.015

89. Ayroldi E, Grohmann U. Exemplifying Complexity of Immune Suppression by a "Canonical" Speech: A Glimpse Into TNFRSF-Activated Signaling Pathways in Treg Cells. Eur J Immunol (2020) 50(7):944-8. doi: 10.1002/eji.202048711

90. Wang J, Zhai X, Guo J, Li Y, Yang Y, Wang L, et al. Long non-Coding RNA DQ786243 Modulates the Induction and Function of CD4+ Treg Cells Through Foxp3-miR-146a-NF-кb Axis: Implications for Alleviating Oral Lichen Planus. Int Immunopharmacol (2019) 75:105761. doi: 10.1016/ j.intimp.2019.105761 
91. Wu J, Niu Q, Yuan J, Xu X, Cao L. lncRNA-CD160 Decreases the Immunity of CD8+ T Cells Through Epigenetic Mechanisms in Hepatitis B Virus Infection. Oncol Lett (2020) 20(1):235-47. doi: 10.3892/ol.2020.11534

92. Jiang R, Tang J, Chen Y, Deng L, Ji J, Xie Y, et al. The Long Noncoding RNA lnc-EGFR Stimulates T-Regulatory Cells Differentiation Thus Promoting Hepatocellular Carcinoma Immune Evasion. Nat Commun (2017) 8(1):115. doi: $10.1038 /$ ncomms15129

93. Fu J, Shi H, Wang B, Zhan T, Shao Y, Ye L, et al. LncRNA PVT1 Links Myc to Glycolytic Metabolism Upon CD4+ T Cell Activation and Sjögren's Syndrome-Like Autoimmune Response. J Autoimmun (2020) 107:102358. doi: 10.1016/j.jaut.2019.102358

94. Kotzin JJ, Iseka F, Wright J, Basavappa MG, Clark ML, Ali M-A, et al. The Long Noncoding RNA Morrbid Regulates CD8 T Cells in Response to Viral Infection. Proc Natl Acad Sci (2019) 116(24):11916-25. doi: 10.1073/ pnas. 1819457116

95. Huang N, Fan Z, Ma L, Ma H, Huang H, Yu H, et al. Long non-Coding RNA RP11-340F14. 6 Promotes a Shift in the Th17/Treg Ratio by Binding With P2X7R in Juvenile Idiopathic Arthritis. Int J Mol Med (2020) 46(2):859-68. doi: $10.3892 / \mathrm{ijmm} .2020 .4618$

96. Liu J-J, Li Y, Yang M-S, Chen R, Cen C-Q. SP1-Induced ZFAS1 Aggravates Sepsis-Induced Cardiac Dysfunction via miR-590-3p/NLRP3-Mediated Autophagy and Pyroptosis. Arch Biochem Biophys (2020) 695:108611. doi: 10.1016/j.abb.2020.108611

97. Nguyen LNT, Nguyen LN, Zhao J, Schank M, Dang X, Cao D, et al. Long Non-Coding RNA GAS5 Regulates T Cell Functions via Mir21-Mediated Signaling in People Living With HIV. Front Immunol (2021) 12:643. doi: 10.3389/fimmu.2021.601298

98. Lu C, Shao X, Zhou S, Pan C. LINC00176 Facilitates CD4+ T Cell Adhesion in Systemic Lupus Erythematosus via the WNT5a Signaling Pathway by Regulating WIF1. Mol Immunol (2021) 134:202-9. doi: 10.1016/ j.molimm.2021.02.018

99. Wang C, Yang S-H, Niu N, Tao J, Du X-C, Yang J-H, et al. Lncrna028466 Regulates Th1/Th2 Cytokine Expression and Associates With Echinococcus Granulosus Antigen P29 Immunity. Parasites Vectors (2021) 14(1):1-11. doi: 10.1186/s13071-021-04795-2

100. Yang C, Feng T, Lin F, Gong T, Yang S, Tao Y, et al. Long Noncoding RNA TANCR Promotes $\gamma \delta$ T Cells Activation by Regulating TRAIL Expression in Cis. Cell Biosci (2020) 10(1):1-13. doi: 10.1186/s13578-020-00383-6

101. Chan WF, Coughlan HD, Iannarella N, Smyth GK, Johanson TM, Keenan CR, et al. Identification and Characterization of the Long Noncoding RNA Dreg1 as a Novel Regulator of Gata3. Immunol Cell Biol (2020) 99(3):323-32. doi: 10.1111/imcb. 12408

102. Bian Z, Lei W, Li Q, Xue W, Gao Y, Zeng Y, et al. Gm15575 Functions as a ceRNA to Up-Regulate CCL7 Expression Through Sponging miR-686 in Th17 Cells. Mol Immunol (2020) 125:32-42. doi: 10.1016/j.molimm.2020.06.027

103. Zhang F, Liu G, Li D, Wei C, Hao J. DDIT4 and Associated Lncddit4 Modulate Th17 Differentiation Through the DDIT4/TSC/mTOR Pathway. J Immunol (2018) 200(5):1618-26. doi: 10.4049/jimmunol.1601689

104. Zhang F, Liu G, Wei C, Gao C, Hao J. Linc-MAF-4 Regulates Th1/Th2 Differentiation and is Associated With the Pathogenesis of Multiple Sclerosis by Targeting MAF. FASEB J (2017) 31(2):519-25. doi: 10.1096/fj.201600838R

105. Huang D, Chen J, Yang L, Ouyang Q, Li J, Lao L, et al. NKILA IncRNA Promotes Tumor Immune Evasion by Sensitizing T Cells to ActivationInduced Cell Death. Nat Immunol (2018) 19(10):1112-25. doi: 10.1038/ s41590-018-0207-y

106. Luo M, Liu X, Meng H, Xu L, Li Y, Li Z, et al. IFNA-AS1 Regulates CD4+ T Cell Activation in Myasthenia Gravis Though HLA-Drb1. Clin Immunol (2017) 183:121-31. doi: 10.1016/j.clim.2017.08.008

107. Gibbons HR, Shaginurova G, Kim LC, Chapman N, Spurlock CFIII, Aune TM. Divergent lncRNA GATA3-AS1 Regulates GATA3 Transcription in THelper 2 Cells. Front Immunol (2018) 9:2512. doi: 10.3389/ fimmu.2018.02512

108. Chen LL, Yang L. Regulation of circRNA Biogenesis. RNA Biol (2015) 12 (4):381-8. doi: 10.1080/15476286.2015.1020271
109. Ding X, Zhang S, Li X, Feng C, Huang Q, Wang S, et al. Profiling Expression of Coding Genes, Long Noncoding RNA, and Circular RNA in Lung Adenocarcinoma by Ribosomal RNA-Depleted RNA Sequencing. FEBS Open Bio (2018) 8(4):544-55. doi: 10.1002/2211-5463.12397

110. Wang F, Nazarali AJ, Ji S. Circular RNAs as Potential Biomarkers for Cancer Diagnosis and Therapy. Am J Cancer Res (2016) 6(6):1167.

111. Zhang L, Zhang K, Fang W, Li H, Li Y, Jiang W, et al. CircRNA-1806 Decreases T Cell Apoptosis and Prolongs Survival of Mice After Cryptococcal Infection by Sponging miRNA-126. Front Microbiol (2020) 11. doi: $10.3389 /$ fmicb. 2020.596440

112. Li LJ, Zhu ZW, Zhao W, Tao SS, Li BZ, Xu SZ, et al. Circular RNA Expression Profile and Potential Function of Hsa_Circ_0045272 in Systemic Lupus Erythematosus. Immunology (2018) 155(1):137-49. doi: 10.1111/imm. 12940

113. Zhang C, Wang X, Chen Y, Wu Z, Zhang C, Shi W. The Down-Regulation of Hsa_Circ_0012919, the Sponge for miR-125a-3p, Contributes to DNA Methylation of CD11a and CD70 in CD4+ T Cells of Systemic Lupus Erythematous. Clin Sci (2018) 132(21):2285-98. doi: 10.1042/CS20180403

114. Zhang C, Zhang C, Ji J, Xiong X, Lu Y. Hsa_circ_0012919 Regulates Expression of MDA5 by miR-125a-3p in CD4+ T Cells of Systemic Lupus Erythematous. Lupus (2020) 29(7):727-34. doi: 10.1177/0961203320920706

115. Huang Z, Cao Y, Zhou M, Qi X, Fu B, Mou Y, et al. Hsa_circ_0005519 Increases IL-13/IL-6 by Regulating Hsa-Let-7a-5p in CD4+ T Cells to Affect Asthma. Clin Exp Allergy (2019) 49(8):1116-27. doi: 10.1111/cea.13445

116. Zhu X, Wang X, Wang Y, Zhao Y. The Regulatory Network Among CircHIPK3, LncGAS5, and miR-495 Promotes Th2 Differentiation in Allergic Rhinitis. Cell Death Dis (2020) 11(4):1-13. doi: 10.1038/s41419020-2394-3

117. Ho I-C, Tai T-S, Pai S-Y. GATA3 and the T-Cell Lineage: Essential Functions Before and After T-Helper-2-Cell Differentiation. Nat Rev Immunol (2009) 9 (2):125-35. doi: 10.1038/nri2476

118. Willimott S, Wagner SD. miR-125b and miR-155 Contribute to BCL2 Repression and Proliferation in Response to CD40 Ligand (CD154) in Human Leukemic B-Cells. J Biol Chem (2012) 287(4):2608-17. doi: 10.1074/jbc.M111.285718

119. Ghafouri-Fard S, Taheri M. Maternally Expressed Gene 3 (MEG3): A Tumor Suppressor Long non Coding RNA. Biomed pharmacother $=$ Biomed Pharmacotherapie (2019) 118:109129. doi: 10.1016/j.biopha. 2019.109129

120. Ghafouri-Fard S, Taheri M. Nuclear Enriched Abundant Transcript 1 (NEAT1): A Long non-Coding RNA With Diverse Functions in Tumorigenesis. Biomed Pharmacother $=$ Biomed Pharmacotherapie (2019) 111:51-9. doi: 10.1016/j.biopha.2018.12.070

121. Roy S, Awasthi A. Emerging Roles of Noncoding RNAs in $\mathrm{T}$ Cell Differentiation and Functions in Autoimmune Diseases. Int Rev Immunol (2019) 38(5):232-45. doi: 10.1080/08830185.2019.1648454

Conflict of Interest: The authors declare that the research was conducted in the absence of any commercial or financial relationships that could be construed as a potential conflict of interest.

Publisher's Note: All claims expressed in this article are solely those of the authors and do not necessarily represent those of their affiliated organizations, or those of the publisher, the editors and the reviewers. Any product that may be evaluated in this article, or claim that may be made by its manufacturer, is not guaranteed or endorsed by the publisher.

Copyright $\odot 2021$ Taheri, Barth, Kargl, Rezaei, Ghafouri-Fard and Pichler. This is an open-access article distributed under the terms of the Creative Commons Attribution License (CC BY). The use, distribution or reproduction in other forums is permitted, provided the original author(s) and the copyright owner(s) are credited and that the original publication in this journal is cited, in accordance with accepted academic practice. No use, distribution or reproduction is permitted which does not comply with these terms. 